\title{
LA COMUNA SAN JOSÉ EN LA MIRA: TRANSFORMACIONES URBANAS Y REDES SOCIALES VISTAS A TRAVÉS DE LA FOTOGRAFÍA
}

\author{
FERNANDO CANTOR AMADOR ${ }^{1}$, MIGUEL ÁNGEL RIVERA FELLNER ${ }^{2}$, \\ JULIÁN ARIEL RAMÍREZ LÓPEZ ${ }^{3}$
}

Recibido el 1 de julio de 2013 y aprobado el 28 de julio de 2013

\begin{abstract}
RESUMEN
A través del "Macroproyecto de Interés Social Nacional para el Centro Occidente de Colombia, Comuna San José, Manizales", desde 2009 se produce una profunda intervención de la Comuna, concebida como renovación urbana. Los problemas en la planeación del proyecto han conducido a la demolición relativamente lenta de un importante patrimonio de la ciudad, tanto de las edificaciones gubernamentales, como de vestigios de una ciudad más importante en términos industriales y de la historia producida colectivamente en los barrios durante más de un siglo. Hasta ahora se aprecian casi mil metros pavimentados del par vial llamado Avenida Colón y los inicios del primer edificio para habitación multifamiliar. Es a través de la fotografía que exponemos el modo en el cual las redes sociales necesariamente se ven afectadas debido a los cambios en las lógicas en el uso del espacio público, así como en la modificación de la vida cotidiana propia de los vecindarios urbanos populares de las comunidades pobres, de manera intempestiva desplazados y con la probabilidad de ocupar apartamentos de 45,15 $\mathrm{m}^{2}$. Estamos ante la afectación de la calidad de vida de las familias y personas de la Comuna. Sin embargo, este cambio no es mirado de la misma forma por los dirigentes políticos de la ciudad. Contamos parte de la historia de la Comuna, finalizando con un retrato de la misma en la imagen de Victorino, uno de sus personajes más conspicuos.
\end{abstract}

\section{PALABRAS CLAVE}

Comuna San José, Manizales, fotografía, redes sociales, espacio público, pobreza, vecindario urbano popular, transformación urbana.

THE SAN JOSE COMMUNE IN SIGHT: URBAN TRANSFORMATIONS AND SOCIAL NETWORKS SEEN THROUGH PHOTOGRAPY.

\section{ABSTRACT}

Through the "National Social Interest Macro Project for the Central-Western area in Colombia, San José Commune, Manizales", since 2009 a deep intervention in that Commune has been taking place, conceived as urban renovation. The problems in the project planning have led to the relatively slow demolition of an important patrimony for the city in both, governmental buildings and remains of a city more important in industrial terms and of the collectively produced history in the neighborhoods during more than a century. So far, more than one thousand paved meters can be seen from the parkway called Avenida Colón and the beginnings of the first apartment block. It is through photography that we expose how social networks are affected necessarily because of the changes in the logics of the use of public space as well as the modification in daily life routines proper from popular urban neighborhoods in poor communes, who are untimely 
displaced and with the possibility to move to 45.15 square meters apartments. This is the affectation of quality of life of families and people in the Commune. However, this change is not seen the same way by the city political leaders. We tall part of the Commune history, finishing with its portrait in the image of Victorino, one of its most notable characters.

\section{KEY WORDS}

San José Commune, Manizales, photography, social networks, public space, poverty, popular urban neighborhood, urban transformation.

\section{PRESENTACIÓN}

El presente artículo tiene como finalidad exponer de un modo sucinto los resultados más relevantes obtenidos de la investigación y el proceso de documentación audiovisual llamado "Victorino: una etnobiografía audiovisual en la Comuna San José en la ciudad de Manizales (Colombia)", financiada con recursos de la Vicerrectoría de Investigaciones y Postgrados de la Universidad de Caldas. Este proyecto respondió a la finalidad de continuar con la denuncia de una situación de vulneración de derechos fundamentales en la mencionada Comuna, hacer eco a las voces de los ciudadanos inconformes con la demolición de su hábitat, contribuir en la construcción-reconstrucción de la memoria demolida, así como proponer mecanismos de acercamiento a los afectados por las políticas públicas que toman cuerpo a través del Macroproyecto de Renovación Urbana.

En este texto, se tratará de llevar al lector desde la generalidad del problema hasta un caso particular, uno entre muchos, pero que consideramos valioso y digno de servir de entrada a un proceso de visibilización de las historias individuales, tan similares y múltiples a la vez, que son afectadas por el Macroproyecto de Renovación Urbana Comuna San José: "Victorino". Y en este cambio de lo macro a lo micro de la problemática, la fotografía (así como el video) fueron cruciales en cuanto permitieron diversos procesos de representación y análisis de esta transformación.

\section{LA COMUNA SAN JOSÉ: A CABALLO ENTRE LOS TRADICIONAL Y LO MODERNIZANTE}

Es común decir en Manizales que estamos viviendo en una ciudad que está a caballo entre lo tradicional y lo moderno, entre la pervivencia del complejo legado de la colonización antioqueña del occidente colombiano y las formas modernizantes (mucho más que modernas) que han modelado el carácter social de la ciudad al ritmo de relaciones con el mercado interno del país y las articulaciones con el mercado mundial, hoy denominado el mundo de la globalización.

La Comuna San José ha tenido que ver con las distintas fases identificables en la constitución como ciudad capital de departamento. La modernización del país, que incluye de manera importante la incorporación de la región andina en la construcción del mercado interno, como desarrollo 
agropecuario y minero que coadyuva a la acumulación de capital para la industria, tiene como pilar la colonización supracitada. Del mismo modo, las guerras civiles del siglo XIX se constituyen en referencia obligada para la fundación de las ciudades, particularmente para Manizales. La construcción de la ciudad tiene sus orígenes en el territorio que hoy conocemos como la Comuna San José, recordando cada cuanto que San José es parte de la ciudad, especialmente en 1925-1926, es decir, cuando el Centro de Manizales se incendió y sus prósperos habitantes intramigraron hacia ese territorio plano que queda al otro lado de la hoy denominada Avenida del Centro o Avenida Gilberto Alzate Avendaño. Es importante resaltar que una de las modalidades más importantes del proceso de modernización de Manizales se juega hoy en el escenario de la misma Comuna, vía Macroproyecto de Renovación Urbana.

Nos encargamos de recordar la historia de Manizales, que se vincula con la misma historia de la Comuna San José, porque -a pesar de señalar desde hace tiempo (Cantor et al., 2010) nosotros ${ }^{4}$ y otras organizaciones no gubernamentales- el Macroproyecto de Renovación Urbana de la Comuna San José debe advertirse como proyecto de ciudad.

Como saben quienes habitan la Comuna San José y los investigadores sociales que transitamos sus barrios, canales, escalas, plazas, manzanas y calles, es mucho más que capítulos del código penal. Es habitada por ciudadanos y ciudadanas, carácter olvidado que facilita la intervención, dado que cualquier tratamiento estatal y privado sería mejor que "habitar ratoneras" 5 y admite la persistente transgresión de los más elementales derechos.

La memoria de la ciudad, siendo selectiva al elegir qué olvida (recordando a Ricoeur, 2008), no se reconoce en los habitantes de la Comuna. Esto se debe, tal vez, a que tenemos una ciudad fragmentada, no porque así lo decida la naturaleza por el carácter agreste del territorio que permita o fomente comunas y barrios fragmentados económica y socialmente, sino porque deliberadamente al mencionar la Comuna se utilizan palabras que incluyen a su gente en actividades tipificadas como delitos: microtráfico de sustancias psicoactivas, muertes violentas, prostitución y delitos contra la propiedad.

La ruptura con las raíces que le otorgan cierta distinción, se realiza no sobre la base de un "superar conservando", como procede la historia en la modernidad, sino que aniquila sus propias fuentes al asumir la modernización, privilegiando no la cultura, no la tradición, no lo social, sino la posibilidad de convertir zonas de renta baja en zonas de renta alta $^{6}$, es decir, colocando como único criterio para el ordenamiento del territorio la generación de plusvalía, la cual valga la pena precisar, a pesar de ser generada socialmente termina siendo capitalizada privadamente, particularmente. Pero, es más modernización que modernidad, porque, adicionalmente elige métodos antidemocráticos en la modernización utilizando a la misma ley, al derecho, como herramienta para desplazar por la fuerza a los propietarios de las viviendas, aquellos que construyeron colectivamente un modo de vida urbano popular, con todos los ricos contenidos de las redes sociales (las reales, no las virtuales) propias de la existencia cotidiana en las barriadas populares.

El desconocimiento de lo popular, de los modos de vida decididos por las comunidades humanas, hace parte de la particular forma de gobernar al 
país y a la ciudad, formas específicas de una democracia ejecutiva que desconoce a los ciudadanos, o al menos a un tipo de estos: los que tienen mayor poder adquisitivo y aumentan la renta. Estos procesos son conocidos en todo el mundo y hacen parte de una competencia global entre ciudades que se venden como seguras, limpias y prósperas a inversores de todo tipo. A este fenómeno se le ha llamado 'gentrificación' y ha sido documentado fuertemente en la última década por investigadores y activistas7.

El Macroproyecto de Renovación Urbana es asumido desde el nivel central como un proyecto de interés nacional, el cual elude por su denominación el control político que debe ser realizado por el Concejo Municipal, hace omisión del Plan de Ordenamiento Territorial o lo "corrige" para adaptarlo al "interés nacional", al tiempo que degrada al gobierno municipal a la administración de un proyecto ejecutado en la ciudad, como política pública sin ciudadanos, sin público. $O$ el público, al menos el directamente afectado, reducido a contemplar, como público de un espectáculo, una puesta en escena de la cual no es protagonista, solo es un actor de tercera, obligado a actuar renunciando a la ciudadanía, a la capacidad de agenciar sus propios derechos.

Este proceso de gentrificación es básicamente un desplazamiento forzado ${ }^{8}$, producto de los grandes proyectos nacionales, sin consulta previa, conducidos con el único interés del capital, es decir, del interés rebajado a la mera acumulación vía desposesión. Para decirlo con las palabras de Harvey (2008):

En el corazón de la urbanización característica del capitalismo radica un proceso desplazamiento y lo que denominamos "acumulación por desposesión". Se trata de la contraimagen de la absorción de capital mediante el redesarrollo urbano, que da lugar a numerosos conflictos en torno a la captura de suelo valioso en manos de las poblaciones de renta baja que han podido vivir en esas ubicaciones durante muchos años. (p. 34)

La participación ciudadana, conditio sine qua non de la democracia, obligación indicada desde la Constitución Política y una frondosa legislación que le regula especialmente para el caso la planeación del desarrollo en todos los niveles de la administración, tanto en lo nacional como en lo subnacional (territorial), es reducida sin más a la socialización de los proyectos, de las decisiones, omitiendo la deliberación, la expresión de la ciudadanía. Asumir la renovación urbana como necesidad perentoria de la Comuna San José no tiene discusión; otra cosa es que el Macroproyecto de Renovación Urbana no ha consultado de un modo eficaz y participativo la realidad de los ciudadanos y las ciudadanas y podría convertirlos de beneficiarios en damnificados. Como más adelante se puede apreciar, las condiciones de calidad de vida en la Comuna requieren la intervención desde el Estado, pero mediada tal intervención por el diálogo de saberes entre la investigación académica, los saberes populares y las propuestas de agencias del Estado, así como los intereses gremiales. Diálogo que no puede ser desconocido como lo está haciendo ahora y menos aún del modo y estilo actuales que desintegran las redes sociales, impeliendo a sus desplazados a cambiar sus modos de vida de manera abrupta. Se trata de establecer un relacionamiento Estado-Universidad-Sociedad Civil (sus fuerzas organizadas), que enriquezca y potencie el encuentro de lecturas, intereses y recursos. 
Desde las posiciones oficiales, se trata de hacer ver cómo un proyecto de carácter social al Macroproyecto que de manera paradójica crea en su interior, a través de la Empresa de Renovación Urbana de Manizales, un capítulo social dentro del mismo que pretende paliar de cualquier manera los impactos negativos generados por su emplazamiento desde hace casi cinco años, simple confesión de la no comprensión estratégica que puede alcanzar el Macroproyecto y expresión de la falta de planeación, que diversas voces, incluyendo a las diversas bancadas políticas en el Concejo Municipal y la Asamblea Departamental, así como las cabezas mayores de la Contraloría General y la Personería Municipal, entre otras agencias de Estado, han criticado de manera persistente y documentada. ${ }^{9}$

Un proyecto de renovación reformulado democráticamente requiere una ciudad que viva la democracia.

La cuestión de qué tipo de ciudad queremos no puede estar divorciada de la que plantea qué tipo de lazos sociales, de relaciones con la naturaleza, de estilos de vida, de tecnologías y de valores estéticos deseamos. El derecho a la ciudad es mucho más que la libertad individual de acceder a los recursos urbanos: se trata del derecho a cambiarnos a nosotros mismos cambiando la ciudad. Es, además, un derecho común antes que individual, ya que esta transformación depende inevitablemente del ejercicio de un poder colectivo para remodelar los procesos de urbanización. La libertad de hacer y rehacer nuestras ciudades y a nosotros mismos es, como quiero demostrar, uno de nuestros derechos humanos más preciosos, pero también uno de los más descuidados. (Harvey, 2008, p. 23).

La democracia en Colombia se presenta a la manera de demo-cracia, fracturando la unidad primigenia, vale decir, helénica, colocando todo el acento en el poder, es decir, en el krátos y desconociendo el demos, el pueblo, como titular del poder, de la soberanía. En la Comuna San José equivale a la destrucción del tejido social, de las redes sociales que permiten la gente viviendo entre la pobreza y que la pobreza extrema pueda sobrevivir.

La modernización se construye de manera inadvertida, como por inercia, porque la ciudad debe cambiar, se pretende que crezca a cualquier costo, sin precisar qué es crecer: tal vez descapotar las montañas en las cuales vivimos transformándolas en pastizales, "limpiarlas", para proseguir el proceso urbanizador; urbanizarlas, es decir, "humanizarlas" dentro de una concepción de dominar a la naturaleza concebido esto como civilización o como cultura. Habrá que recordar que la Ley 135 de 1961 o de reforma agraria estimuló la destrucción de los bosques, como condición para la titulación de la tierra a los colonos, a los campesinos. No en balde, Horkheimer y Adorno (2001) identifican el concepto de dominación como aquel que elimina el carácter crítico de la llustración, rebajándola a razón instrumental. Dominación originalmente dirigida hacia o contra la naturaleza, pero que termina por traducirse en opresión del mismo hombre, dentro del proceso de cosificación, de alienación prefigurado por Marx (1982) en los Manuscritos de París. Esta concepción de dominación, símbolo de la misma colonización antioqueña, símbolo hecho realidad en la iconografía de la colonización en los aserradores, en el hacha, en los 
devastadores de los bosques, termina por someter a la misma naturaleza humana, dominándola y convirtiéndola en mera mercancía. La demolición de la Comuna San José expresa la frontera nueva de la colonización, en nombre del progreso la demolición de las mismas construcciones humanas, comunitarias.

La demolición se traduce en intervención sobre el espacio, modificando el paisaje. Empero, el paisaje humano solo es demolido, sin avanzar en la superación de la pobreza y la pobreza extrema. Si comparamos una fotografía tomada en enero de 2010 desde el Corredor Polaco en la Catedral de Manizales, con otra que se tome en enero de 2014 (siendo optimistas respecto a la aceleración de la lentísima marcha de las obras civiles en la construcción del par vial y los primeros apartamentos VIP) o dentro de 10 años con la consolidación de las demoliciones y el levantamiento de los multifamiliares, de manera similar a otros proyectos de renovación urbana, la Comuna San José sometida a una operación quirúrgica con todo el cuidado de las topadoras y las retroexcavadoras, habrá arrancado toda la pobreza exterior expresada en las fachadas de las casas, en el desaseo que a veces acompaña a la pobreza, pero las causas de la pobreza y sus trampas, no se habrán reducido. No se trata de profetizar desastres, pero si no hay un tratamiento integral, los apartamentos nuevos alojarán la vieja pobreza, que es la pobreza de hoy, basada en la inequidad y la falta de oportunidades.

\section{La Comuna: hogares y vecindades}

La Comuna San José es un vecindario urbano popular configurado por unos 28.500 habitantes en 2009, es decir, antes de comenzar el desplazamiento forzado, estando la población organizada en unos 5.500 hogares. Si bien las estadísticas muestran que estamos ante una población fluctuando entre la pobreza y la pobreza extrema, tal pobreza es mucho más que una calificación en términos de calidad de vida: es, también, un estilo de vida, un modo de vida. Desde la metodología empleada por el Banco Mundial para medir pobreza, la Comuna San José se mueve entre la pobreza y la pobreza extrema: $39 \%$ y $43 \%$, respectivamente. Precisando este asunto con la nueva investigación en curso del Colectivo Antonio García10 el 69\% de los que trabajan en la Comuna ganan hasta un salario mínimo mensual. El ingreso del $26 \%$ de los hogares oscila entre uno y dos salarios mínimos mensuales. Empero, la pobreza y la calidad de vida, que se presentan como otra forma de medir condiciones de vida de una comunidad, aparecen también como resultado de una pluralidad de dimensiones a considerar, atendiendo a que la existencia humana está definida más allá del ingreso, es mucho más compleja. Esto es necesario a tener en cuenta, si consideramos con Amartya Sen que la pobreza no solo es carencia de dinero, sino la incapacidad de las personas para desarrollar todo el potencial humano. Para ello miramos más adelante algunos "factores de la pobreza".

La pluralidad de factores que pueden definir la pobreza, examinados como indicadores de la misma en la Comuna, dado que debemos contar con exteriorizaciones de la vida comunitaria que nos permitan ver qué es lo que ocurre, son -entre otros factores relevantes-: la educación, permite advertir que si agrupamos a los jefes de hogar sin escolaridad, con primaria incompleta, primaria completa y secundaria incompleta, suman el $80 \%$. Esto se reafirma con la asistencia escolar en el grupo etario 25-34 años en donde la ausencia llega al 90\%; y el 60\% entre 15 y 24 años. Es decir, 
niveles de formación extremadamente bajos para habitantes urbanos en los comienzos del siglo XXI.

Las supracitadas limitaciones de formación corren parejas con el empleo informal, es decir, precario, en donde si sumamos el empleo no calificado y aquel definido por la OIT (Organización Internacional del Trabajo) para América Latina, como de servicios y vendedores, agrupa al 65\% del trabajo en la Comuna. Correlativamente, agrupando trabajo manufacturero e industrial, con empleados y operarios de ensambladores, apenas llega al $22 \%$.

De manera importante encontramos que de los jefes de hogar11 que trabajan el $72 \%$ no están afiliados a fondos de pensiones; de todos los habitantes que trabajan, el $83 \%$ no se afilian a sistemas de pensiones. Con todo lo anterior, a lo cual sumamos que el $92 \%$ de las personas no están en capacidad de ahorrar dinero, inferimos que la posibilidad de acceder a los apartamentos VIP (Vivienda de Interés Prioritario), de solo $45,15 \mathrm{~m}^{2}$, es prácticamente nula, ello teniendo en cuenta la experiencia de las familias en los multifamiliares en la ciudadela del Norte en el barrio San Sebastián, uno de los principales barrios en la recepción de desplazados de la Comuna San José. Solo pueden aspirar a ser propietarios si los subsidios estatales cubren el 100\% del precio de los apartamentos. Pagando 180 mil pesos mensuales de cuota más 140 mil pesos entre servicios públicos y administración, sumamos 320 mil pesos12, cifra inalcanzable para hogares apenas sobreviviendo en la pobreza por las lógicas de las redes sociales reales que se construyen en los vecindarios urbanos populares. Como se ha advertido, en febrero de 2013 solo el 10\% de los habitantes de San Sebastián están al día en los pagos mensuales. Es insostenible la situación de las familias, lo cual seguramente se repetirá, si este proyecto urbano sigue adelante con sus pautas desconocedoras de la realidad social y económica. No sobra precisar que solo el $47 \%$ de los hogares habitan vivienda propia.

A pesar de todo lo anterior o precisamente por lo anterior, la gente de la Comuna tiene como propósito claro, el empeño en seguir habitando en el territorio construido en una historia de más de un siglo. El 75\% de la gente expresa estar muy satisfecha o muy satisfecha con la vivienda. ${ }^{13}$ En una lectura que introduce una variedad de factores, se colige que esta satisfacción es también con el vecindario, con la probabilidad y más aún la certeza del trabajo en la Galería, los arrendamientos baratos, la posibilidad de no gastar dinero en transporte para poder llegar a lugares clave: el mismo Centro de la ciudad, los hospitales, los centros educativos y distintas agencias de Estado que ofrecen servicios a los ciudadanos. Es bien importante la clasificación de la Comuna San José en los estratos 1 y 2 que garantizan servicios públicos subsidiados. Pero, aquellos que tienen vivienda propia valoran sobremanera este hecho, independientemente de las condiciones físicas y estéticas porque se consideran privilegiados frente a aquellos que pagan arriendo. Condensa esta satisfacción, el ambiente construido colectivamente, el vecindario barrial, la comunidad de intereses y el sentirse entre iguales.

Como se advierte en las fotografías, los frentes de algunas casas no anuncian lo que encontramos en el interior de las viviendas. Sin anunciar visita la experiencia vivida en la mayor parte de los hogares fue el de una pobreza con gran limpieza en cada uno de los espacios que configuran la vida cotidiana. Las fachadas están deterioradas en buena parte de la 
Comuna, sin embargo, el cuidado interior es distinto. Contrastan también los olores de las calles con los de las casas. Se puede "leer" de esto que el cuidado por lo propio, explica la satisfacción por la vivienda, advertida en las encuestas aplicadas, así como en las charlas informales y las entrevistas semi-estructuradas. Sencillamente procuran los habitantes que el vecindario, especialmente su propio patio esté decorosamente presentado.

Como las personas, los barrios, las calles, los parques van construyendo su personalidad, de tal modo que se puede presentar la semblanza de los territorios. Solo que para que tenga sentido la semblanza, como en las personas que no hacemos semblanzas de colectivos o grupos sociales demasiado masivos, tenemos que continuar el ejercicio originalmente realizado por el Colectivo Antonio García al zonificar la Comuna y distinguir lo que mirado desde lejos aparece homogéneo (Cantor et al., 2010). Ahora, nos empeñamos en mirar más de cerca, en respirar en el mismo ambiente descrito e interactuar con las personas que contribuyen a configurar el alma del barrio, de la cuadra, sin ser precisamente conscientes de lo que hacen.

La vivienda además se ha convertido en elemento central para acentuar las dinámicas propias de la calle, al definir los criterios de lo que es público y lo que es privado, que provienen en gran medida de las concepciones de lo social de las comunidades que habitan barrios populares. En este sector, el uso del espacio social de la vivienda, como la sala o comedor, lugares que se usan para compartir en familia o recibir a otras personas, se amplía hasta el andén o la calle, convirtiéndose estos lugares "nuevos", que no coinciden con las definiciones convencionales de área social -que las reducen al interior de la vivienda-, en sitios de reunión entre vecinos, familiares y amigos.

Cuando llegan las fiestas de Navidad, los vecinos se rebuscan para decorar la calle o la cuadra, algunos tenderos regalan dulces para las novenas y donan anchetas y regalos para los niños; otras personas consiguen los cerdos y gallinas que se van a preparar para compartir con los vecinos de la calle o cuadra; las fiestas de quince años que se hacen por el sector, casi todas con mariachis, se preparan con al menos un año de antelación. Desde cuando se programan se comienzan a hacer rifas, se venden empanadas, buñuelos o comidas; algunos se especializan en el corte de cabello y cuidados de las uñas, también para recolectar fondos. La gente va de casa en casa acudiendo a la colaboración de los vecinos para recaudar lo necesario que permita hacer la celebración. En los bautizos, primeras comuniones o matrimonios, es normal que un mismo vestido sirva para varias ocasiones y entre los vecinos hacen ese tipo de concesiones.

A pesar de los grandes emplazamientos comerciales y supermercados que se han situado últimamente en la ciudad y en el territorio de la misma Comuna San José, las tradicionales tiendas de barrio se siguen resistiendo a esa lógica comercial y aún mantienen las ventas al detal o fraccionadas, en los sectores populares. La permanencia de estas tiendas de barrio se debe esencialmente a dos factores: el primero, tiene que ver con las estrechas relaciones que se generan con el tendero basadas en la confianza y la solidaridad; en la tienda se prestan servicios variados a los habitantes del barrio:

[...] como la recepción y transmisión de mensajes entre los vecinos, la publicación de información de interés general, la 
vigilancia respecto al movimiento de gente extraña o de personas sospechosas, siendo de esta manera los lugares favoritos para la discusión de problemas comunes o para el conocimiento de las noticias del día ya sea producidas al interior del barrio o en el contexto nacional o internacional. (García y Arias, 2007, p.4)

El segundo factor tiene que ver con que en la tienda de barrio además "persiste el fiado confiando solo en la palabra; también el regateo y la 'ñapa', como las más auténticas expresiones de las relaciones establecidas entre tendero y consumidor" (García y Arias, 2007, p.6). Este tipo de relación tendero-vecino del barrio no puede ser remplazada en su riqueza comunitaria por las grandes superficies, caracterizadas por la despersonalización o por la cosificación de las relaciones sociales.

La dinámica comercial que tiene en general la Comuna, determinada principalmente por la presencia de la Galería (el centro de acopio y distribución de abastos agropecuarios más antiguo e importante de la ciudad) y todos los procesos que se generan a su alrededor, ha contribuido a que la gente perteneciente a esta zona de ladera, identifique y reconozca cada uno de los sitios que ofrecen algún servicio. Saben dónde están ubicados los puntos de transporte; los lugares para la diversión como los famosos billares de "Parra", "La Rockola" y "La Sonrisa"; los sitios de servicios sexuales como "Las Pereiranas", "La casa de Saturia", "Japonesita", "Media Luna" y "14-10"; los centros de medicina alternativa y los de consultas astrológicas; los sitios gastronómicos como el de "doña Martha", "Mi Viejo", comidas rápidas "Gallo" y los restaurantes de la Galería; la zona de reparación y mantenimiento o "sector Liborio", y los almacenes de depósitos de café, madera, insumos de construcción y reciclaje. Servicios en su mayoría que están ubicados en el sector de la Galería y la parte central de la Comuna, por el barrio San José. Pero todo esto está cambiando, lenta pero inexorablemente.

\section{ANÁLISIS DEL IMPACTO DE LA RENOVACIÓN URBANA EN LA COMUNA SAN JOSÉ A PARTIR DE LA FOTOGRAFÍA}

Este apartado tiene como finalidad sugerir un análisis de los impactos sociales de la transformación urbana, inspirado en dos formas de acercamiento etnográfico, pero aplicadas con medios fotográficos: la etic y la emic. Sin entrar en detalles ni especificar los puntos en los cuales no convergemos con Kenneth Pike (1991), basta decir que estas modalidades de acercamiento sugieren un punto de vista alejado, o en perspectiva, y un punto de vista cercano, o particular, específico; respectivamente.

En el primero, es decir, desde la perspectiva etic, se construyen comparaciones fotográficas a partir de encuadres y reencuadres que nos muestran un antes y un después desde inicio del proyecto de renovación urbana. En ellas se sugiere a grandes rasgos un análisis discursivo, textual y contextual sobre el paisaje urbano y vecinal de los diferentes barrios intervenidos reciente y lentamente con este plan de reordenamiento urbano. Esto, sin entrar en los detalles de lo que la gente percibe y del modo en el cual entiende esta transformación. 
En segunda instancia, es decir, la emic, y continuando con la denuncia de los impactos inmedibles de la renovación urbana, se realiza una aproximación documental microhistoriográfica a partir de álbumes de fotografías familiares en tres barrios de la Comuna San José: La Avanzada, Sierra Morena y Galán. En ellos se trató de leer la relación entre ese espacio público transformado y las redes sociales que afecta. Este análisis fotográfico parte de conversaciones con los dueños de algunos álbumes familiares privados y su diferencia con la perspectiva etic radica en que estas fotografías no fueron producidas con una finalidad académica o generalizante, sino con una finalidad más íntima y doméstica, y que refuerzan una manera de ver la vida.

Para finalizar, retomamos las reflexiones y experiencias de uno de los afectados directamente por esta transformación urbana, combinando las perspectivas etic y emic. Victorino, así como cada habitante de la Comuna, es un nodo de interacciones en esas redes sociales (reiteramos, las offline) representadas en los álbumes familiares, y su historia de vida ha servido para documentar audiovisualmente el contexto coyuntural de las transformaciones individuales y colectivas de un proyecto de amplias dimensiones infraestructurales, económicas y sociales.

Pero antes de entrar en materia, vale resaltar la necesidad de complementar estas perspectivas emic y etic. Siguiendo la reflexión de Naranjo (2006), estas fotografías se convierten en imágenes para repensar esta transformación desde las personas que la viven. Más allá de medir (que era lo que se buscaba con la fotografía hasta comienzos del siglo XX) o de solo observar (como lo hicieron muchos antropólogos con la fotografía), este ejercicio se debe concebir como un punto clave para la reflexión de la ciudad que construimos y de nuestro papel como ciudadanos.

\section{Antes, durante y... (Fotografía etic)}

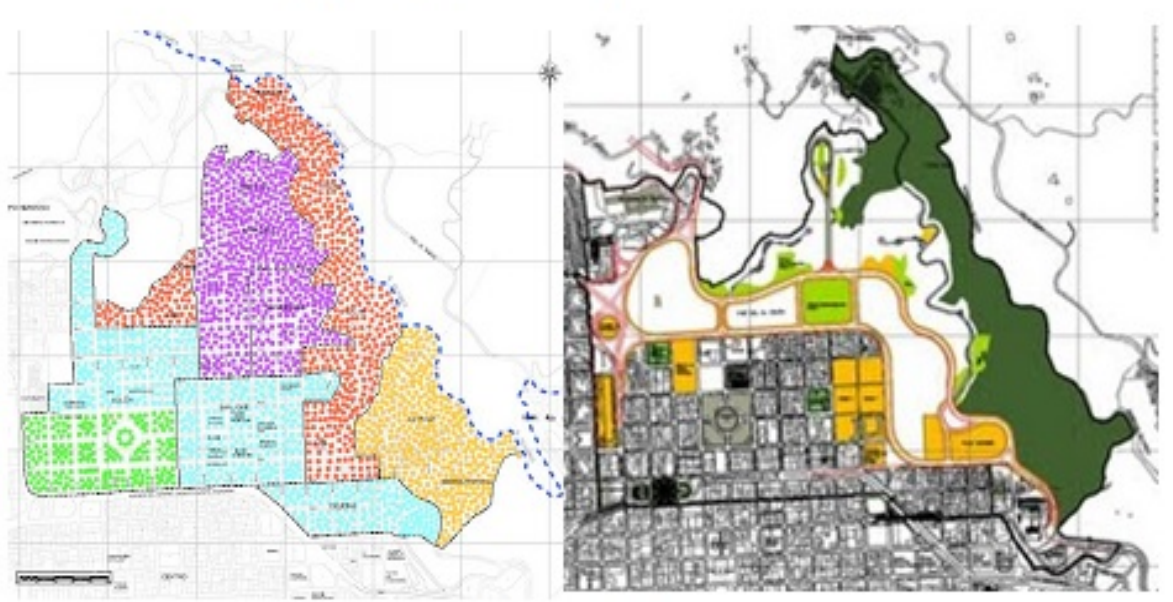

Mapas 1 y 2.

Si tomamos como referencia a estos dos mapas, vemos cómo la zona centro norte, así como toda la zona este, se modifican más profundamente. La Comuna en estos momentos no está representada por ninguno de estas gráficas, ya que la de la izquierda era la Comuna hasta el 2009 y la derecha apenas se está esbozando en el territorio. En el mapa de la izquierda, se diferencian cinco sectores de la Comuna antes del proyecto de 
transformación urbana: en verde el sector de la Galería, en azul la zona central, en violeta La Avanzada, en naranja una zona de invasión y en rojo la zona de ladera (también invadida); este mapa es tomado del Colectivo Antonio García [El Carácter Social de la Comuna San José en tiempos de renovación urbana (Cantor et al., 2010)]. El mapa de la derecha, se refiere al mismo espacio y se encuentra disponible (aunque en muy baja resolución), en el blog de la Sociedad de Mejoras Públicas de Manizales (http://smpmanizales.blogspot.com/2010/03/en-manizales-se-creo-uncomite-de.html); en este mapa se condensa el objetivo final del proyecto, en donde sobresalen las zonas grises y verdes, separadas por una demarcación roja tenue que indica el paso de la Avenida Colón; la zona demarcada en gris al parecer quedará por fuera del cambio infraestructural aquí resumido, mientras que la zona en verde será recuperada por el municipio para hacer obras de amortiguamiento; las zonas amarillas se refieren a adecuaciones de equipamiento urbano.

El tiempo estimado para la finalización de las diferentes obras se ha dilatado varias veces, quedando atrás muchos de los procesos más importantes (como la construcción del gran colegio o la adecuación de la zona de ladera), estando casi finalizada, eso sí, la Avenida Colón. Las seis fotografías que se presentan a continuación hacen parte de un proceso investigativo basado en la comparación y la "reconstrucción" de algunos escenarios barriales intervenidos públicamente por el proyecto de renovación urbana ejecutado sobre la Comuna San José, entre los años 2009 y 2013, respectivamente. Estos escenarios son mirados de manera descriptiva y comparada, gracias a composiciones fotograficas logradas en dos temporalidades distintas; primero, cuando el proyecto no había impactado de manera directa la vida de las personas que habitan este espacio urbano de la ciudad de Manizales. Y por otro lado, se logran reencuadrar algunos escenarios barriales de la Comuna, cuando infraestructuralmente ha sido intervenida parcial y violentamente por la empresa de renovación urbana.

Es a partir de estos paralelos que se evidencian las transformaciones urbanísticas que implican cambios en los modos de habitar y representar ese espacio urbano de la Comuna San José, generando nostalgias, angustias y preguntas en aquellos que han configurado durante décadas redes sociales y memoria colectiva en la ciudad, y que además, la han visto desvanecerse en el aire en unos pocos meses.

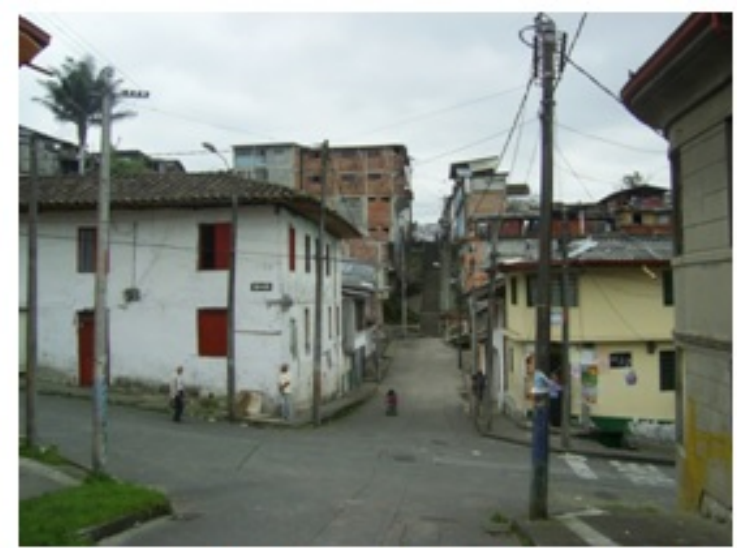

Fotografia 1. Barrio La Avanzada en la calle 28, Comuna San José. Fecha: abril de 2011. Archivo: FOCUS. 


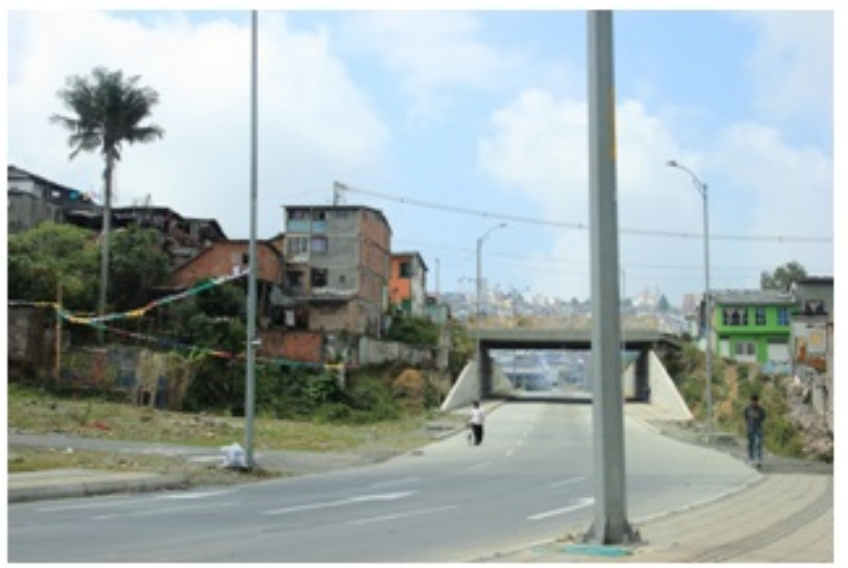

Fotografía 2. Barrio La Avanzada en la calle 28, Comuna San José. Fecha: marzo de 2013. Archivo: FOCUS.

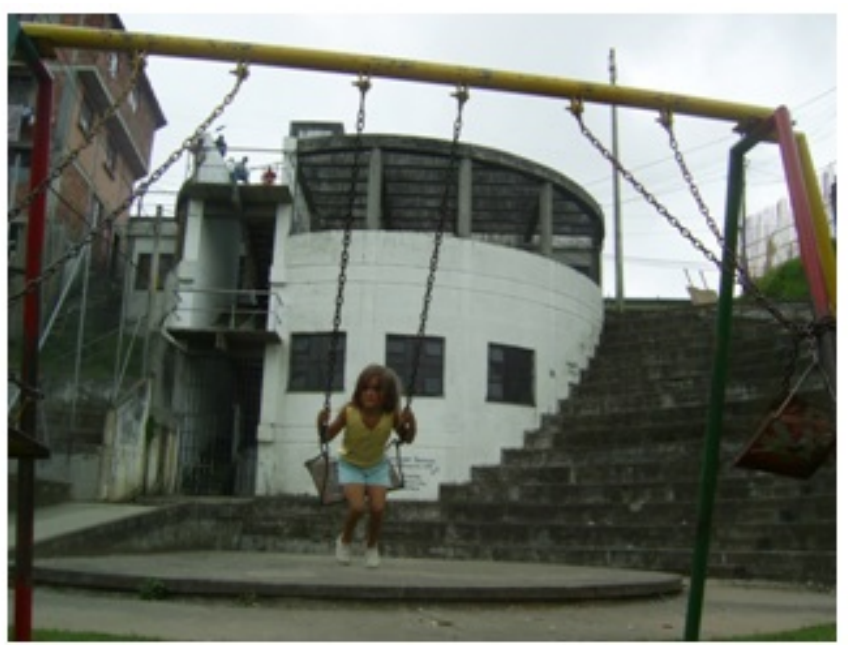

Fotografía 3. Barrio La Avanzada en la calle 27 en la entrada del Camino del Medio, Comuna San José. Fecha: febrero de 2010. Archivo: FOCUS.

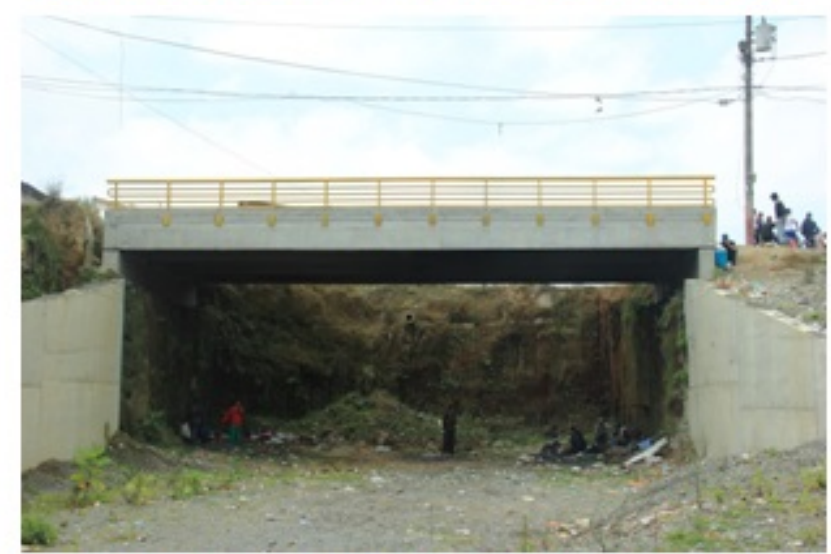

Fotografía 4. Barrio La Avanzada en la calle 27 en la entrada del Camino del Medio. Comuna San José. Fecha: mayo de 2013. Archivo: FOCUS. 


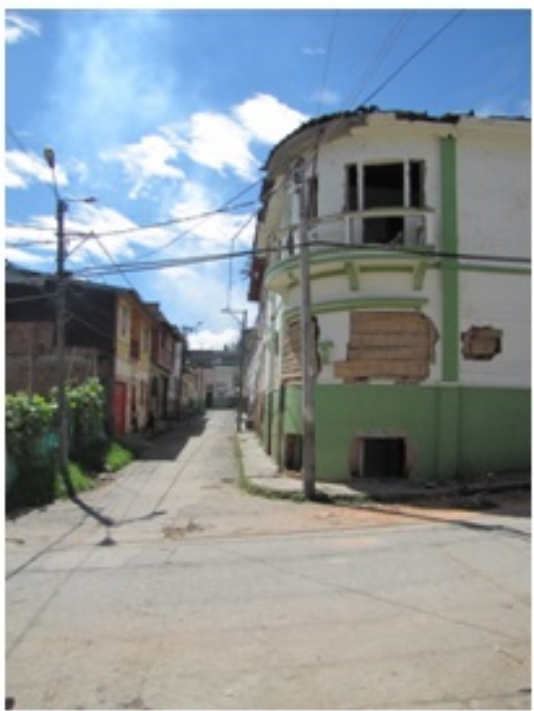

Fotografía 5. En el barrio Colón en la calle 24 carrera 11a, Comuna San José. Fecha: junio de 2010. Archivo: FOCUS.

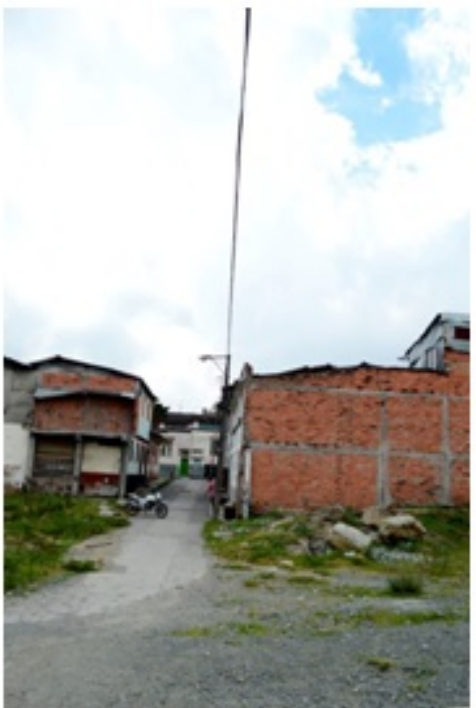

Fotografía 6 . En el barrio Colón en la calle 24 carrera 11a, Comuna San José. Fecha: mayo de 2013. Archivo: Focus.

Las fotografías son siempre la representación de un pasado, son el testimonio de una historicidad cambiante del mundo social que queda enmarcada brevemente en la traducción química o digital que hace el medio audiovisual de la luz y de los espacios a través de las películas o los sensores que captan y componen la imagen en la fotografía. Cuando este proceso ocurre, el mundo ha continuado su curso y el flujo de la vida indifectiblemente persiste, dejando a la imagen fotográfica en un tiempo pasado y en la noción del hecho ocurrido, tanto para el fotógrafo como para el público que la observe.

En el caso que nos compete, el flujo de la vida en los barrios de la Comuna San José se ha visto acelerado de manera abrupta, y esto no ha permitido la elaboración de una representación que permita la comprensión del impacto en los espacios urbanos intervenidos con el proyecto de renovación urbana; comprensión necesaria para una configuración activa y contextualizada de un futuro urbano basado en los derechos humanos y en la responsabilidad social del Estado y sus ciudadanos. Este es un primer intento en esta vía. Pero para que esto sea completo, se debe tener una perspectiva más íntima con las redes y los significados tejidos en estas calles.

\section{Redes sociales y espacio público (fotografía emic)}

La finalidad de este apartado es indagar, de un modo general, sobre los usos y las implicaciones que la fotografía trae consigo para la comprensión de las redes sociales (no virtuales) que se han tejido históricamente en este importante sector de la ciudad de Manizales, exaltando, además, la necesidad de reivindicar una parte de la memoria de los barrios y hacer consciente la existencia de una realidad compartida, en momentos como el que ahora atraviesa el sector con la ejecución del proyecto de renovación urbana de la Comuna San José. 
Como se ha tratado de mostrar, este proyecto ha requerido el desplazamiento de cientos de familias y de negocios a otros sectores de la ciudad, modificando de manera extrema varios de los espacios públicos de la Comuna. Es decir, con la renovación se ha provocado la transformación forzosa de espacios que simbólicamente se han dotado de mística e historias colectivas, reflejadas física y territorialmente en la cotidianidad de vida en los barrios y en las viviendas de la diversa Comuna San José.

Llamamos trasformación forzosa a la problemática estructural del proyecto de renovación en la Comuna, ya que no hubo concertación con la población urbana en desplazamiento. Además, la búsqueda de una supuesta disminución de la desigualdad y la exclusión en este sector fue la perspectiva más ignorada en la planeación y ejecución, a pesar de ser una de las justificaciones institucionales de tal transformación. Esta omisión dificulta seriamente el cumplimiento de la misión social del mismo, pues su imposición ha generado malestar en los hogares y familias intervenidas. Esto se debe a que la velocidad de las obras en el sector y las opciones de nueva vivienda de la renovación no permiten una adaptación óptima, ni en términos económicos ni en términos sociales.

Las fotografías que reposan en los archivos domésticos y comerciales de los habitantes de la Comuna, brindan pistas valiosas para comprender esas configuraciones sociales que se ven completamente afectadas por la renovación urbana. Así como también hacen posible acercarse a las dinámicas propias en relación con los espacios públicos que se han constituido como territorios compartidos y apropiados mucho antes de ser intervenidos con obras públicas, especialmente en barrios como La Avanzada. Es decir, los álbumes familiares en estos barrios populares, son una fuente indispensable para entender los procesos socioeconómicos y culturales de la configuración de la Comuna, de acuerdo con el desarrollo de la historia y la apropiación colectiva e individual de las diversas zonas de las que se compone la Comuna San José, siendo estas fotografías pequeños fragmentos representacionales de una realidad sociocultural imbricada por la democratización de las nuevas tecnologías y el encuentro vertiginoso con una modernización fuertemente católica (como se verá en las fotografías).

Estos álbumes familiares, al menos a los que hemos podido acceder hasta el momento en los barrios Galán, Sierra Morena y La Avanzada, deben ser entendidos no solo como una especie de insospechados archivos de la memoria de los barrios y las familias que allí habitan, sino también como formas de socialización y productos de una economía visual; siguiendo a la antropóloga Deborah Poole (2000): considerar a estos álbumes y sus fotografías como formas y productos de una economía visual, implica verlos como objetos y como símbolos, los cuales son producidos, intercambiados y consumidos en contextos que varían siempre, aunque sea en mínimos aspectos, y que poseen tanto un valor de uso como un valor de cambio.

Este énfasis en la "economía" de lo visual más que en la "cultura" de lo visual, responde a la necesidad de ver a las imágenes (en este caso, a las fotografías y sus diversas formas de acumulación y conservación doméstica) más allá de elementos curiosos, idiosincráticos o pintorescos de ciertas formas de representación, ya que hacen parte del sustrato mismo de esas formas de representación y de construcción de fronteras e identidades (Poole, 2000, p. 16). Es decir, al hacer énfasis en la economía de lo visual se hace explícita la necesidad de ver a la ideología, a lo simbólico y a la 
memoria social como aspectos representacionales que se dinamizan, surgen y son socializados en intercambios concretos, en gran medida mediados por imágenes.

En otras palabras, y siguiendo a Hans Belting (2002), el análisis de las imágenes no se puede hacer sin considerar su corporeidad, su medio de transmisión. Esto se debe en gran medida, a que el medio permite indagar sobre cómo se produjeron esas imágenes. También permite indagar cuáles han sido las condiciones históricas y económicas implícitas en su circulación, acumulación y consumo en los escenarios urbanos y populares, es decir, en el significado que posee la materialidad de las imágenes como formas de narración del contexto cultural, económico y social y que se encuentra anclado en una especie de memoria colectiva.

En este contexto, los álbumes familiares y demás colecciones fotográficas domésticas, son considerados como elementos usados para la socialización y el afianzamiento de conexiones establecidas entre las personas, al ser estas imágenes las que representan la visión interna, compartida y aceptada del mundo, tanto del que obtura la cámara fotográfica, como del que presta su imagen para ser fotografiada. Eso es compartido por Susan Sontag (1981), quien analiza la implícita relación de complicidad entre los que producen, distribuyen y consumen imágenes, relación básicamente mediática en la cual se inserta el proceso de creación de las imágenes mentales a través de las imágenes materiales.

Por ejemplo, al remitirnos a los aspectos más significativos exaltados en la fotografía doméstica de la Comuna San José, nos encontramos con uno de los espacios públicos de mayor relevancia icónica, no solo de la historia de los 16 barrios de la Comuna, sino para gran parte de la historia económica y política de la región caldense del norte y el oriente de Caldas y la ciudad de Manizales. En la Fotografía 7 resaltamos entre su implícita polisemia aspectos tales como la manera como el fotógrafo y los fotografiados son cómplices de la representación y el performance visual de un momento de sus vidas en la integración y apropiación familiar y pública del extremo norte de la Comuna: el Puente Olivares.

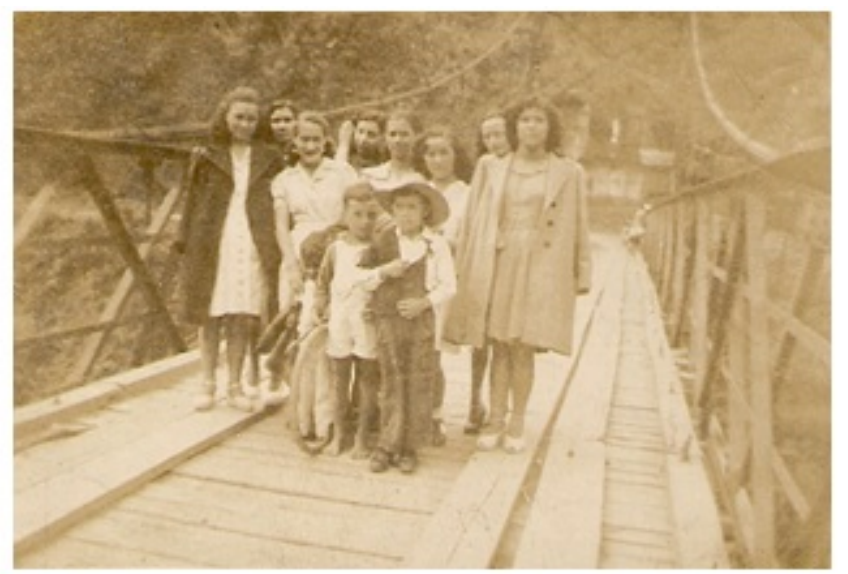

Fotografia 7. En el Puente Olivares aproximadamente en el año 1958. Se encuentran presentes algunas personas de la Familia Ramirez, entre ellos los en ese momento niños: Gabriel Ramírez, José H. Ramírez y Arturo Ramírez, antiguos habitantes de la Comuns San José, en la calle 30, en el tercer pasaje del barrio Galán. Archivo: Familia Ramírez. 
Estas fotografías se entienden como unidades dotadas de significados sociales y culturales diversos, no asociadas necesariamente con la objetividad de la realidad de la Comuna San José, sino que se entienden como textos en los que se evidencian discursos, narrativas, perspectivas, intenciones, rasgos y rastros de la historia individual y colectiva de los seres humanos que las producen y las dotan de sentido. En el caso de la Comuna San José, por ejemplo, los signos impresos en las fotografías son analizados a partir del contexto cultural en el que fueron elaborados y compartidos en los escenarios domésticos de conservación y consumo.

En este sentido, se puede ver la importancia que se le asigna intencionalmente a los encuadres y al lenguaje corporal que se representan en las fotografías en distintos escenarios públicos y situaciones sociales de carácter religioso y familiar. Esto se nota específicamente cuando la fotografía se utiliza para destacar y legitimar determinados discursos íntimos o públicos de las familias, como fueron por ejemplo los procesos de reasentamiento territorial que se desarrollaron en la ciudad desde iniciado el siglo pasado, a partir de los puentes y senderos comunicativos y comerciales que se propiciaron con el ingreso progresivo de personas, vehículos y enseres de todo tipo al Centro y la Galería de Manizales, desde municipios vecinos a la capital caldense, especialmente desde el oriente y el norte. Esto ha significado para la Comuna San José, ser un "paso obligado" de la mayoría de los procesos de distribución y asentamiento territorial de Manizales, al menos hasta finales del siglo pasado.

La polisemia de las fotografías domésticas es un aspecto que hay que abordar necesariamente cuando los discursos se han difuminado en el paisaje creado por el plan de renovación urbana, y cuando esos discursos se encuentran en el imaginario y la memoria colectiva que se ha tejido en la cotidianidad de las calles, las cuadras, los andenes y las esquinas, en donde progresivamente los espacios de socialización se han ido deteriorando por el abandono inminente de muchas familias y hogares de los barrios de la Comuna San José producto de la actual transformación física.

En la Fotografía 8, se traen a colación las tradiciones religiosas que se ejecutan en las relaciones públicas de la población, especialmente alrededor de la Iglesia y el Parque San José. La fotografía que se cita, fue realizada en lo que se podría denominar la columna vertebral de la Comuna San José: la calle 27. Se trata de la procesión del Viernes Santo, fundamento del imaginario católico de los pobladores, al tiempo que es, probablemente, el más importante evento religioso del departamento de Caldas. Esto reafirma la devoción católica a la Virgen María y a San José, expresada en la consagración de la Comuna y algunos barrios a los personajes religiosos, así como en la existencia de altares en los hogares con su icónica presencia.

La calle 27 atraviesa varios barrios de la Comuna San José, específicamente desde el Puente Olivares hasta el Parque San José y la Galería, involucrando en gran medida al barrio La Avanzada en su extensión. De esta manera, no parece extraño que se hayan replicado las prácticas culturales en este escenario, como es por ejemplo la distribución territorial de las viviendas en torno a una Iglesia Católica que ordena ideológica y socialmente a la población, como se ve en pleno barrio San José. 
El barrio La Avanzada por su parte, es uno de los espacios más significativos del sector, ya que por su geografía semi-llana ha sido un territorio estratégico en el poblamiento inicial de la ciudad, de allí su nombre. En los relatos orales se conservan algunas reseñas de cómo este camino permitió a la avanzada antioqueña acercarse e integrarse a través de la Comuna San José al Centro de la ciudad, pareciendo ser entre las cimas, una pequeña recompensa a los largos y aguerridos caminos recorridos que a mula o en jeep (devenidos en los yipaos de hoy) realizaran después sus descendientes.

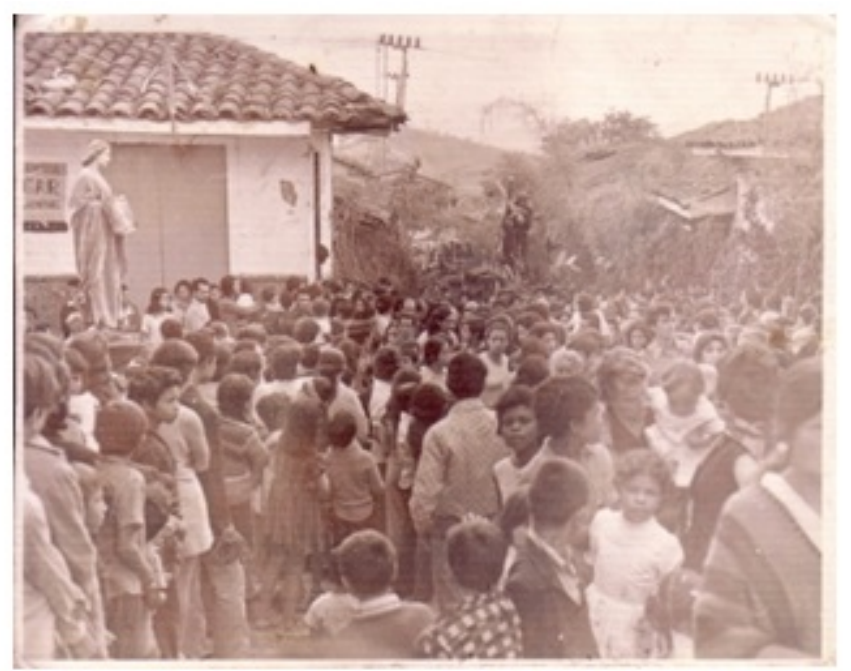

Fotografía 8. Procesión de Semana Santa (década de 1950, aproximadamente). Desde hace más de 20 años que la procesión no pasa por esta ruta, que iba desde El Tachuelo hasta el Parque San José, y atravesaba todo el barrio La Avanzada. La solemnidad del rito y su altísima concurrencia de personas (al menos durante la época en la que fue tomada la fotografía) hacen de esta fotografía algo único, y sorprende que su propietaria la tenga por azar, ya que la ha cuidado durante más de 50 años. Archivo: Martha Zapata.

Otro aspecto que se debe tener en cuenta en el análisis de la fotografía doméstica, a parte de los elementos iconográficos e históricos expresados en las imágenes, es el uso de la práctica fotográfica como un acto y un mecanismo simbólico de legitimación de diferentes poderes. Para explicar esto, es pertinente introducir brevemente a Pierre Bourdieu (1965) en relación a la discusión que se propone sobre el papel de la fotografía en la consolidación de las formas de diferenciación y dominación social, en el afán de algunos grupos familiares de obtener distinción, como ocurrió por ejemplo a nivel nacional con los incesantes esfuerzos de la familia Acevedo por legitimar y manipular abiertamente el poder económico, político y cultural del país con el dominio de la industria del cine y la televisión en Colombia, como lo analiza David Zapata (2012) en su trabajo de pregrado: La nación en cuadro.

De todos modos, el prestigio y los significados culturales que se lograron con la fotografía familiar en la Comuna San José, no se asemeja a la compleja relación que instauraron los Acevedo con los medios de comunicación y representación en la configuración de una nación idealizada e imaginada. Sin embargo, ese material fotográfico de la Comuna San José, es invaluable en la sintetización y consolidación en el tiempo de unos cánones basados en el estatus y el orden social, expresados como ritos del culto doméstico, los cuales tienen la función familiar de "solemnizar y eternizar los grandes momentos de la vida de la familia, reforzar en suma la integración del grupo familiar reafirmando el sentimiento que tiene de sí 
mismo y de su unidad" (Bourdieu, 1965, p. 57). De esta manera, se entiende que el álbum familiar, al ofrecer una cronología, expresa una "verdad" del recuerdo social.

Con lo anteriormente citado se puede considerar que la fotografía en la Comuna San José ha cumplido una función indispensable en la composición y la comprensión de la realidad familiar y vecinal en cuanto a la interacción con el pasado y el presente, los cuales son representados de manera artística y casi armónica en la cronología de los álbumes fotográficos, que aunque reposen en lugares recónditos y privados de los hogares de la Comuna, son los que narran un pasado de la vida histórica, social y cultural de los habitantes de este sector de Manizales.

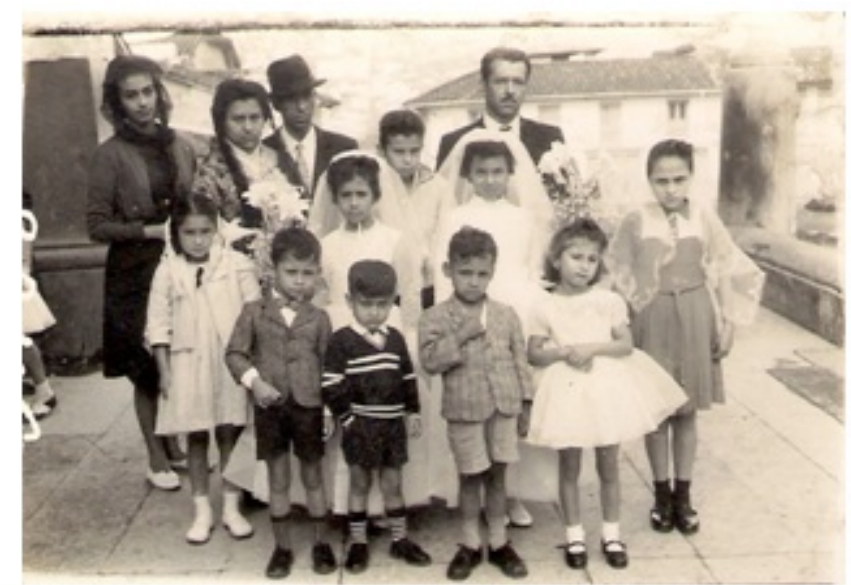

Fotografía 9. En la Iglesia San José, calle 27 carrera 16. Fecha: diciembre 26 de 1962 Foto Rivera. Integrantes de la fotografía: (parte superior) Elvia Castro, Sara Rosa Ramírez, Gabriel Ramírez (sombrero), Luis Ramírez y Jesús Ramírez. Julialba Ramírez Rivera, Marleny Ramírez Cardona (niñas Primera Comunión). Gabriel Ramírez, José H. Ramirez, Arturo Ramirez y Olga Ramirez Rivero (niños, parte inferior). Archivo: Familia Fonsecs.

Bourdieu (1965) explica además, que la fotografía ratifica la función de crear y recrear al grupo, proporcionando el medio de expresión para solemnes momentos culminantes de una persona y en los que el grupo social se reafirma constantemente, como por ejemplo, las bodas, los bautizos, primeras comuniones, procesiones, navidades y graduaciones, que son considerados como hechos importantes en el imaginario heredado de Occidente. Coincidiendo con García (2006), la fotografía se introduce en estas festividades públicas y privadas de diferentes maneras, dependiendo de la ocasión que se celebre y el número de parientes y vecinos que se involucren. 


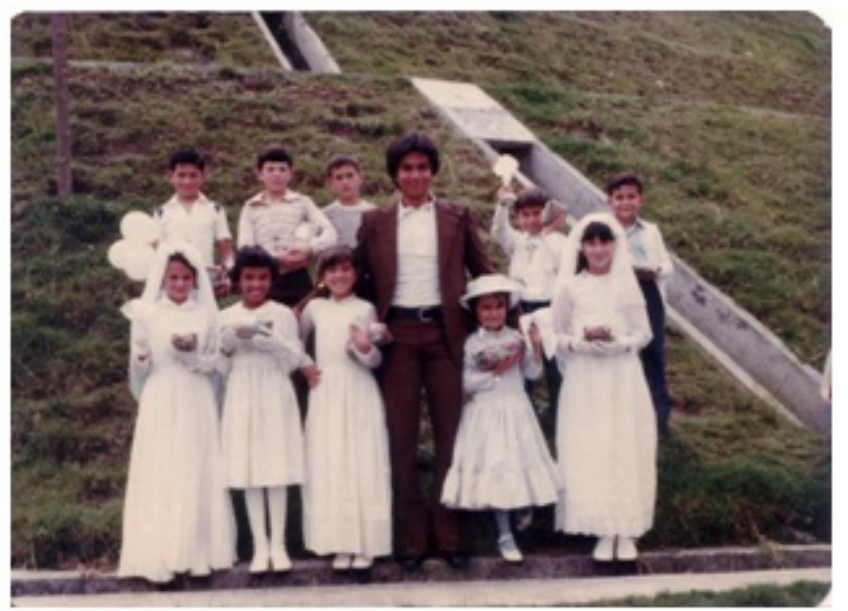

Fotografía 10. Primera Comunión en el barrio Estrada (principios de la década de 1980). El uso de los espacios públicos para conmemorar y solemnizar un evento religioso se ve consolidado y conservado en esta representación fotográfica. Cortesía: Francia González.

Este acercamiento a los álbumes fotográficos, sirve como punto de contraste para reconocer la importancia de los espacios públicos en la configuración de las redes sociales, redes que han sido aisladas progresivamente por el plan de renovación urbana que continuamente está desplazando a los habitantes de la Comuna a otras áreas urbanas y rurales de la ciudad, encauzando la memoria colectiva del sector hacia el olvido intencional.

A continuación se sintetizan algunos hallazgos de la investigación realizada a partir de la descripción de ejemplos fotográficos extraídos de álbumes familiares de los tres barrios mencionados. Se hará referencia a un álbum familiar en el barrio Sierra Morena, adquirido a través de la lideresa Francia González. Por otra parte, se ha logrado reconstruir otro álbum fotográfico desarrollado casi todo en las inmediaciones del alto barrio Galán, con la familia Ramírez Ramírez, cuyos familiares han sido pobladores históricos de esta parte de la Comuna San José. Y finalmente, se tuvo la oportunidad de hacer indagaciones de dos álbumes en el barrio La Avanzada, con las señoras Martha Zapata y Rebeca Fonseca.

Para acceder a estos álbumes familiares se debió tener un acercamiento previo, que permitiera la consolidación de un mínimo de empatía y confianza para poder acceder a estas colecciones privadas, ya que muchas de ellas contienen recuerdos dolorosos e información íntima que se debe proteger. Dos casos en este sentido se nos presentaron. El primero de ellos es una familia con un negocio de alimentos de largo aliento en la Comuna llamado "La Flor del Pandeyuca", de la cual se ha sabido que cuenta (o contaba) con un álbum fotográfico familiar y del negocio que permitía conocerlo de cerca. Sin embargo, al tratar de contactarse con ellos y al conocer nuestros objetivos, se negaron completamente y aseguraron no querer volver a recordar su tiempo en la Comuna San José; incluso aseguran haber eliminado la colección que tenían. Otro caso, menos desafortunado, se presentó con unas de las fotografías a las que se tuvo acceso. Estas contenían imágenes de una persona que pasó por la vida de la propietaria del álbum y dejó recuerdos dolorosos, por lo cual estas fotografías han sido recortadas o modificadas de alguna manera que impidan ver a la persona indeseada. En otros casos, las fotografías han sido modificadas en su composición, pues al morir alguna de las personas 
que integran las imágenes, estas son recortadas y sacadas de la fotografía, casi como un símbolo de su partida material de la vida social y del vacío.

Estos aspectos nos señalaron explícitamente la necesidad de ser cautelosos a la hora de preguntar y de recorrer momentos que han quedado en el pasado pero que tienen una fuerza inusitada en el presente y que tal vez, por el desuso de los álbumes, emergen sentimientos que pueden afectar a la persona que comparte su colección. Pero hay otro problema, y es la vastedad y complejidad de la economía visual. El método de la economía visual nos permite identificar, al menos en abstracto, tres contextos básicos: el de producción, el de circulación y el de consumo. Al inicio de las indagaciones se creía que no habría problema con la identificación de estos tres, ya que en realidad parecen superponerse en el caso de las fotografías domésticas, pero no es necesariamente así. Explorando los álbumes familiares a los que se tuvo acceso, e indagando sobre los orígenes de las fotografías, se lograron identificar al menos cuatro orígenes de las fotografías (de las cuales ninguna se explora aquí a profundidad): 1) el propietario actual, 2) familiares y allegados del propietario actual concurrentes al evento o situación, 3) fotógrafo aficionado, y 4) fotógrafo profesional contratado -sobresaliendo en la zona: Foto Rivera y Puntilla-.

Explorar detalladamente estas formas de producción y de consumo es algo que se hace necesario, pero especialmente la forma en la cual circulan, ya que es en este aspecto en donde parecen ayudar más a la comprensión de las redes sociales que se tejen en la Comuna y que tienen como vehículo a estas imágenes-objeto. Hay un problema adicional al estudiar la compleja red de intercambios de fotografías domésticas o personales: el auge de las tecnologías digitales (problema que a una eventual investigación no afectaría especialmente por el énfasis en álbumes familiares). Debido a que nuestras principales fuentes de información son amas de casa (una de ellas es lideresa) sin acceso a una cámara fotográfica para hacerse un álbum, básicamente nos concentramos en el contexto del consumo (cómo las percibe, qué recuerdos le trae), pero siempre se averiguaba por su procedencia y adquisición (de donde sobresalieron los fotógrafos mencionados).

Doña Rebeca Fonseca del barrio La Avanzada, es una de las personas entrevistadas en ese análisis del consumo y el contexto de procedencia y adquisición de las fotografías que se encuentran en los álbumes domésticos de la Comuna. Ella conserva en cajas pequeñas de metal en los anaqueles de su vivienda, la herencia de un material fotográfico diverso que logró su padre como fotógrafo aficionado desde principios de los años 50 en la Comuna San José, aprovechando la llegada al país de cámaras fotográficas que se conseguían a precios relativamente módicos en el mercado, al igual que las películas con las que se cargaban dichas cámaras. Relata doña Rebeca que recuerda a su padre impresionarse al ver a las monjas del colegio donde ella estudio su bachillerato, en el Colegio La Divina Providencia, tomar fotografías de sus indumentarias y sus celebraciones públicas. 


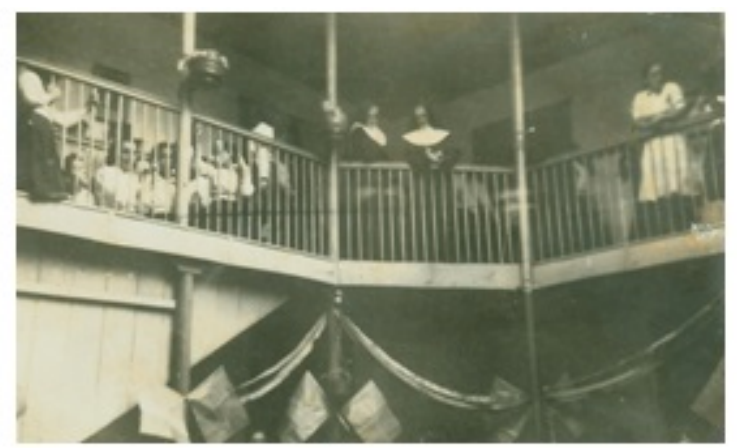

Fotografía 11. En el Parque San José, antes Parque Rafael Uribe Uribe, calle 27 carrera 16, en el interior del Colegio La Divina Providencis. Año: 1960. Archivo: Familia Fonseca.

Fue desde ese momento que según ella, comienza el interés de su padre por la fotografía. Un gusto que se profundizó más cuando vio sus propias imágenes en el papel fotográfico, luego de que las llevara a revelar en los estudios del fotógrafo profesional que más se desataca de la Comuna. El fotógrafo Rivera tenía un estudio de fotografía, donde revelaba fotografías y atendía a sus clientes cuando buscaban un estudio para los retratos, y a los cuales representó de manera honorable cuando retratarse era una verdadera ceremonia que implicaba el vestido especial, adecuarse a una pose respetable en un escenario preparado, permanecer inmóvil un tiempo, y luego el fogonazo, el retoque y tal vez la necesidad de tener que repetir la toma de la fotografía.

Fue a partir de esta práctica artística con la cual José Fonseca se retrató a sí mismo y a su familia en diferentes escenarios cotidianos de la vida familiar y comunal del barrio. Seleccionando en la mayoría de las ocasiones encuadres que reflejan una atmósfera de felicidad y alegría en los integrantes de la imagen, de forma que ni siquiera cuando la familia hubiese tenido serios problemas domésticos estos se veían reflejados explícitamente en ellas. Configurando intencionalmente un ideal solemne sobre cómo debe estar la familia en el tiempo y en el espacio de la Comuna, un mensaje moral y estético implícito para las generaciones subsiguientes en la familia Fonseca.

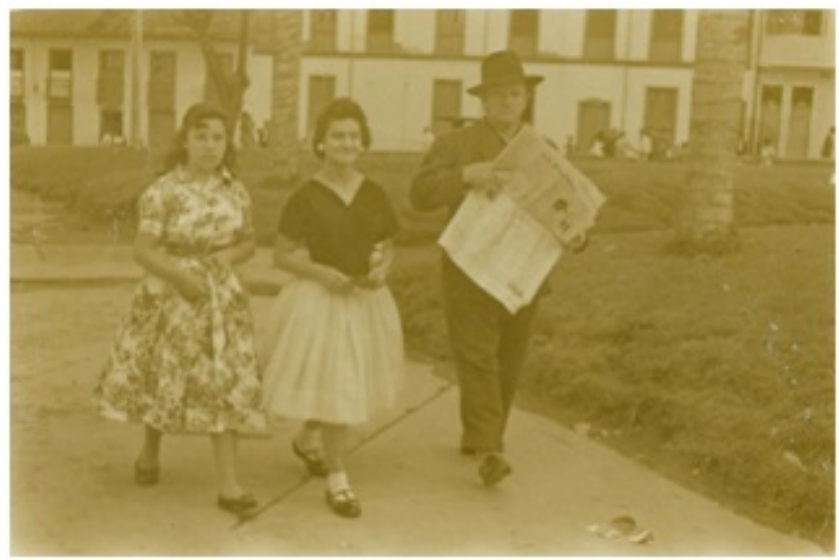

Fotografia 12. En el Parque San José, antes Parque Rafael Uribe Uribe, calle 27 carrera 16. Año: 1960. Foto Rivera. Integrantes de la fotografía: Rebeca, Mirian y José Fonseca. Archivo: Familis Fonsecs. 
Por otra parte, al concentrarnos en el tema del espacio público y el análisis de la economía visual de la Comuna San José por medio de los álbumes familiares, debe entenderse en primera medida, el concepto de lugar como aquellos espacios compartidos en las historias, los cuales, están llenos de tensiones, apropiaciones y significados sociales, de los cuales las fotografías no son testigos fieles, pero sí permiten generar contextos de interpretación en relación con las condiciones e intenciones de las que emergieron como imágenes fotográficas. Es en este sentido que se plantea una arqueología de la apropiación y la significación de los lugares de construcción y desarrollo de la vida social y material de los seres humanos, y estos, a través de la fotografía.

Lo cierto es que lo colectivo, lo social, se ha transformado dramáticamente debido a las situaciones de naturaleza exterior a la vecinal como la economía nacional. La renovación urbana, implica también un cambio de los esquemas de percepción y acción, de los habitus, para usar la conceptualización bourdiana, de prácticas interiorizadas en largos periodos de vidas enmarcadas por la sociedad en la que forman sus actitudes las personas frente al entorno. En este sentido, los lugares son espacios significativos en los que las relaciones que se establecen entre las personas configuran una trama de redes sociales, en las que se arman lazos identitarios, no como un conjunto de vínculos planos y estáticos sino como un proceso de remodelación, de cambio, con todas las características de la movilidad que presenta un concepto tan complejo.

La fotografía doméstica tiene, por lo general, retratos individuales, retratos colectivos, conmemoraciones públicas y privadas, y muchas de estas representaciones tienen a niños y jóvenes como protagonistas en escenarios del espacio público. Esto se debe en gran medida a la importancia que se le da en nuestra sociedad a estas épocas de la vida, importancia que ya se manifestaba con la cantidad de ritos religiosos y etarios, así como al carácter público de estas ceremonias aparentemente privadas.

El espacio público ratifica en la fotografía el carácter social del individuo, permite enmarcarlo y ofrecerle un telón de fondo, a pesar de que ese espacio no sea propiamente un protagonista o un interés del enfoque fotográfico. En este caso, no importa tanto la apropiación individual del espacio público como la apropiación colectiva, debido al énfasis en las conexiones familiares, institucionales y vecinales, que aquí se busca y que se evidencia en el formato reiterativo de tales fotografías conmemorativas (lo cual se puede ver en las Fotografías 9 y 10). Este entendimiento de las redes sociales en interacción con el espacio público, será un poderoso insumo de planificación y ordenamiento justo del nuevo espacio asignado por las autoridades que coordinan el Proyecto de Renovación Urbana.

Pero no solo los niños y los adolescentes son dignos de ser representados. Los líderes y las personas mayores se vinculan poderosamente con los espacios en donde han crecido, trabajado y por lo tanto han contribuido a la construcción y transformación de sus barrios. En las fotografías que a continuación se muestran, es posible apreciar el papel preponderante del varón en la constitución familiar, pero también, en especial en la Fotografía 16 , el valor de matriarcas que incluso después de la muerte convocan. 

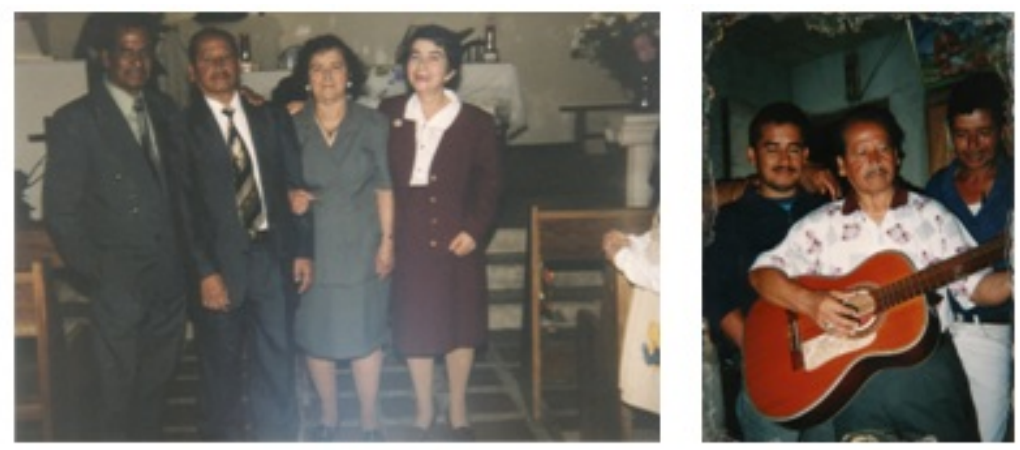

Fotografias 13 y 14. Don Carlos en diferentes eventos sociales (aproximadamente décadas de 1980 y 1990). Las fotografías de los álbumes familiares están repletas de momentos y personajes como este, don Carlos, un líder de los barrios Sierra Morena y Estrads, que deja de ser un referente eminentemente familiar para ser una figurs del barrio. Estas fueron unas de las primeras fotografías que nos trajo doña Francia González al solicitarle fotografías importantes para conocer el barrio, lo que muestra cómo el carácter de lo público, de lo compartido, de la convivencia, pasa necessriamente por líderes que posibiliten cierta unidad. Cortesía: Francia González.

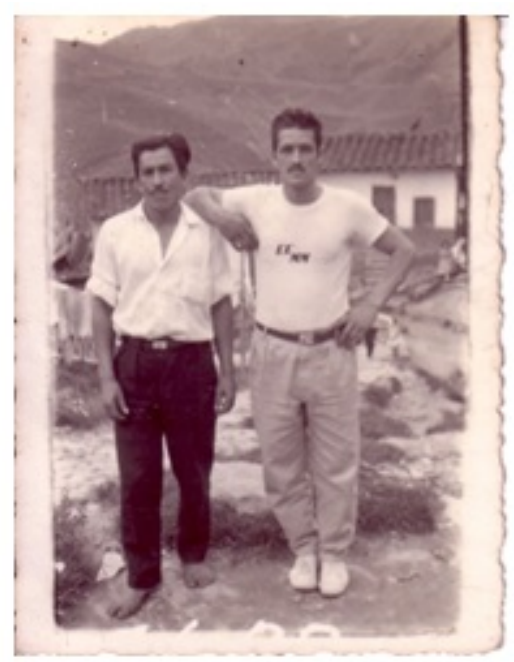

Fotografía 15. Tomada por el fotógrafo Rivers en junio 9 de 1961, en La Avanzada. Esta fotografía llegó a las manos de doña Martha gracias a una práctica que ella nos asegura que ha realizado siempre su familia, y entre los vecinos, de heredar las fotografís de sus padres. Esta era de su madre y en ella se encuentran su tío y su primo, pero no sabe dónde ubicar la fotografía exactamente, ya que la configuración del espacio ha cambiado drásticamente desde entonces. La guardó porque estos objetos eran caros y contenían recuerdos importantes para ella y su familia. Archivo: Martha Zapata. 


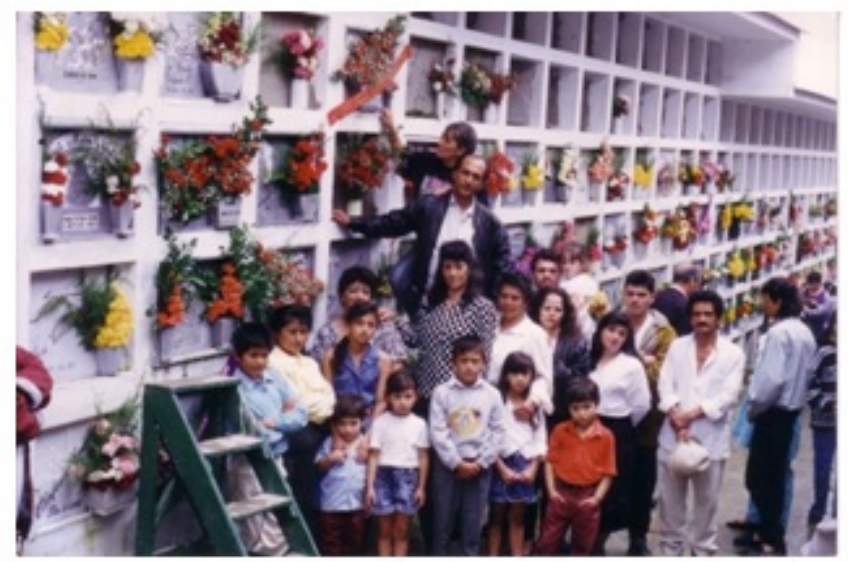

Fotografía 16. Fotografía del Día de la Madre (mediados de la década de 1990). Si bien el cementerio San Esteban no hace parte de la Comuns, esta fotografía evidencia al menos dos aspectos clave de la socialización de sus habitantes, y es la conexión con sus muertos, sus ancestros y sus seres queridos perdidos (y de paso se ratifica la ubicación estratégica de habitaren esta zona de la ciudad). El otro aspecto que evidencia es el uso que hacían los padres del espacio público (como organización de eventos vecinales y luchs por dotación urbana), ya que en esta foto se encuentran persongs que no son familiares directos, sino vecinos. Archivo: Marths Zapsta.

Con respecto a la vida en el barrio, las ganas de departir y las fiestas populares en las calles de la Comuna han desaparecido, específicamente porque sus habitantes han migrado hacia otros barrios, como San Sebastián, Sinaí, El Carmen, entre otros. El proyecto económico de renovación urbana, ha difuminado también los deseos de establecer redes entre los vecinos. Hay una especie de desintegración de las relaciones, de los vínculos y de los afectos entre familiares y entre vecinos. A esto se le suma la supresión de un conjunto de prácticas populares por ir en contra de las disposiciones de salubridad y seguridad públicas, como el manejo de la pólvora y la carnicería a cielo abierto.

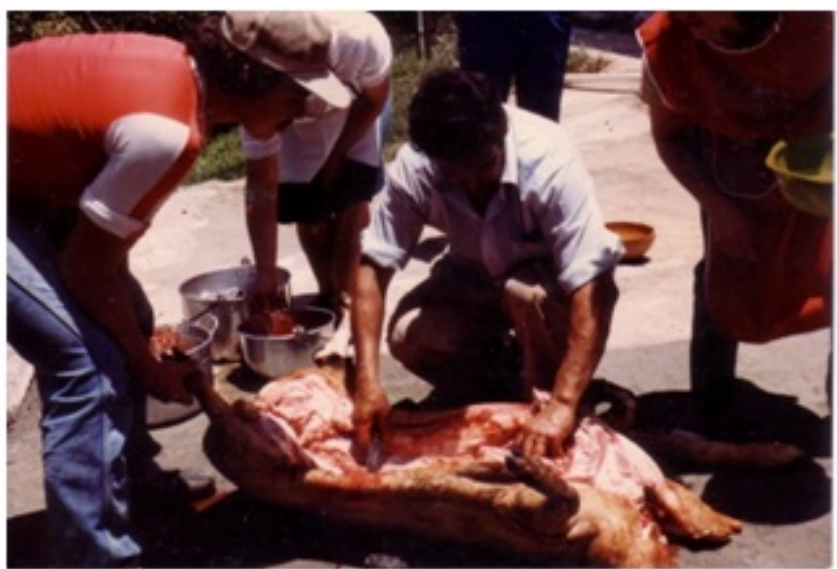

Fotografía 17. Sacrificio de marrano comunitario (década de 1980). De un modo más profano que en los ejemplos anteriores (en donde veíamos a personas solemnes con poses planificadas), en esta escena vemos sí la ritualidad mas no solemnidad en la que insiste Bourdieu cusndo habla de la clase burguess en Francis. La calle del barrio es squel punto de interconexión que amplía la sala y la cocins, por lo cusl, pars un exhaustivo análisis, tendremos que volver a estos espacios semiprivados para comprender cómo ahora se transforman esos espacios públicos de socialización que se están destruyendo y reconstruyendo. Archivo Marta Zapata. 
A pesar de toda la riqueza y fuerza que puedan tener cada una de estas fotografías, estas no son sino fragmentos de vidas en relación, que permiten ver sus lugares en común al tiempo que los diferencia individualmente. Ahora bien, teniendo en cuenta esta reducción sociocultural sobre la particularidad y la subjetivista de las múltiples narraciones que se pueden descifrar y redimir a través de las imágenes, se expone el enfoque, prisma u óptica con la cual, literalmente, se ha observado, encuadrado, escuchado y descrito a la Comuna San José durante más de 25 meses.

Para esta presentación se tiene en cuenta principalmente el concepto de etnobiografía retomado de la postura intelectual, ética, estética y política del investigador argentino Jorge Preloran, quien ha dedicado más de 20 años de su vida al desarrollo de una etnografía audiovisual basada en la descripción exhaustiva, la participación de los sujetos de estudio y la reconstrucción e indagación profunda de las historias de vida de sujetos paradigmáticos en la representación y la crítica a las realidades conflictivas de Latinoamérica, casi con el deseo de someter al espectador al sufrimiento y al tedio temporal y sensorial de los conflictos en este lado del mundo, a través del uso y la conjugación magistral en la edición de las voces en off y los planos subjetivos y largos, producidos de manera espontánea pero controladamente, en la vida cotidiana de estos sujetos. Es decir, que sus trabajos audiovisuales han sido manifiestos históricos y críticos con aires de venganza estilizada, exotizada y finamente contados por los mismos sujetos de estudio en un tono individual que refleja en lo colectivo. Estos sujetos son las piezas fundamentales de todo el proceso de investigación y realización audiovisual. Esto fue lo que Preloran denominó en su momento etnobiografía, una conjugación entre el marco conceptual y técnico de la etnografía y la biografía. ${ }^{14}$

Por estas razones, más que considerarlo a Victorino un informante estrella, se ha considerado la imagen de un personaje de la Comuna San José, el prisma o el eje central de la narración de un fenómeno socioeconómico, político y cultural que está en constante lucha y cambio, no solo a nivel local, sino también global como ya lo hemos discutido. Victorino no es un héroe y menos un objeto de estudio o una cifra cuantificable. Es en cambio, un joven que ha construido una red de amigos y de contactos muy importante a nivel local y regional, que le han ayudado a construir a su vez, un discurso de carácter reflexivo, crítico y propositivo sobre la Comuna que recorre a diario y que conoce desde que era un infante.

A continuación se da apertura a la temática investigativa planteada para posteriormente entrar en la recta final del documento, el cual, sugiere un epílogo concluyente sobre el presente y futuro de la Comuna San José.

\section{Victorino: una etnobiografía audiovisual}

Continuando con la descripción y el abordaje del trasegar de las múltiples transformaciones que a diario sufre la Comuna San José de la ciudad de Manizales, tanto por los dinamismos internos que regulan los diferentes aspectos de las relaciones socioeconómicas y culturales, así como por las fluctuaciones externas que ha traído consigo el Macroproyecto de Renovación Urbana para el flujo de la vida social de la Comuna, los cuales ya hemos tenido la oportunidad de analizar a través del texto y las fotografías; nos tomamos la tarea de continuar destacando en este momento de la redacción, la importancia que poseen las narraciones y los 
discursos de los diferentes sujetos sociales y culturales en la construcción, reconstrucción y comprensión de los múltiples escenarios que constantemente están mutando según los procesos territoriales, afectivos, identitarios y socioculturales externos que se involucran en la edificación e interpretación de una realidad alterada y renovada con el proyecto urbanístico en la ciudad.

Victorino, en este caso, es el protagonista de un documental en construcción que sirve de seguimiento a estas transformaciones forzosas ${ }^{15}$, al ser parte de ese paisaje urbanístico que configura lo espacial, lo habitacional y lo relacional en la Comuna San José, pareciese para un observador foráneo que él se desplazase lentamente y sin ningún significado entre esos escenarios de escombros, renovación y demolición de la Comuna, como si fuese un elemento más en ese performance de la ciudad y de la barrialidad que ahora se representa con el Macroproyecto San José. Estos observadores foráneos se podrán distraer fácilmente con las muletas en las que se apoya Victorino para desarrollar confluencia y complicidad entre sus vecinos y familiares en las esquinas, las cuadras y las viviendas en las que cotidianamente se desenvuelve, y en las que ciertamente ha logrado unos lazos trascendentales de solidaridad y amistad que día a día refuerza con su presencia y su discursividad sobre las muletas.

En la creación de esta etnobiografía audiovisual en la Comuna San José, se han dispuesto como recursos narrativos dos elementos esenciales. Primero, la creación de contrapuntos territoriales y sociales, tanto con la renovación urbana (antes, durante y después de la Renovación Urbana), como con los contrastes socioeconómicos que presenta la ciudad y que se hacen evidentes con el Macroproyecto de Renovación. Y segundo, la conjugación de lo documental y lo ficcional con miras de lograr una mayor verosimilitud en la etnobiografía y en la narración total del documental. Siendo ambas las líneas dramáticas que desean sugerir el problema de fondo de la investigación.

Víctor Caicedo, el protagonista del documental, es una hebra del universo configurado histórica, económica, social, política y culturalmente en la Comuna San José. Una condensación de este escenario de lo social, que puede ofrecer una representación del transcurrir de la vida de algunos jóvenes de los sectores populares y marginales de las ciudades, como ya lo ha hecho Víctor Gaviria con "Rodrigo D. No futuro" (1990), y "La Vendedora de Rosas" (1999), dos películas hechas en Colombia en los sectores populares de Medellín. Considerando que han existido y existen en los barrios y comunas del país, muchos "Victorinos" que reviven y escenifican diariamente los actos que nuestro protagonista en algún momento de su vida protagonizó y que desafortunadamente lo dejó en condición de discapacidad física. Siendo esta condición una de las consecuencias más desafortunadas que deja la vida delictiva, a la vez que lo convierten a él en un referente social.

Narrar la historia de Víctor a través de la etnobiografía audiovisual, es narrar entonces las cotidianidades y regularidades de la vida de muchos niños y jóvenes que han crecido en el universo de lo popular y la miseria, pero también es narrar las particularidades de un sujeto que ha construido parte de su historia, que ha logrado romper los cánones sociales para dibujar trazos propios en los que la ayuda a sus congéneres, es uno de sus principales propósitos. El Víctor de estos tiempos, a sus 25 años, portador 
en su cuerpo de una vendetta y heredero de todo ese bagaje oscuro de la pobreza, se constituye como uno de los jóvenes más reconocidos de la Comuna en la actualidad, un reconocimiento trazado no solamente por sus antiguas acciones ilegales, sino por su liderazgo en la búsqueda de salidas al dilema de la pobreza mental y económica de la gente. Esto, a través de la construcción de posibilidades educativas y laborales, para sortear lo que pareciera ser es el rumbo ineludible de la vida de muchos jóvenes de estos sectores marginales de la ciudad, como son la delincuencia, la prostitución, la violencia y la drogadicción.

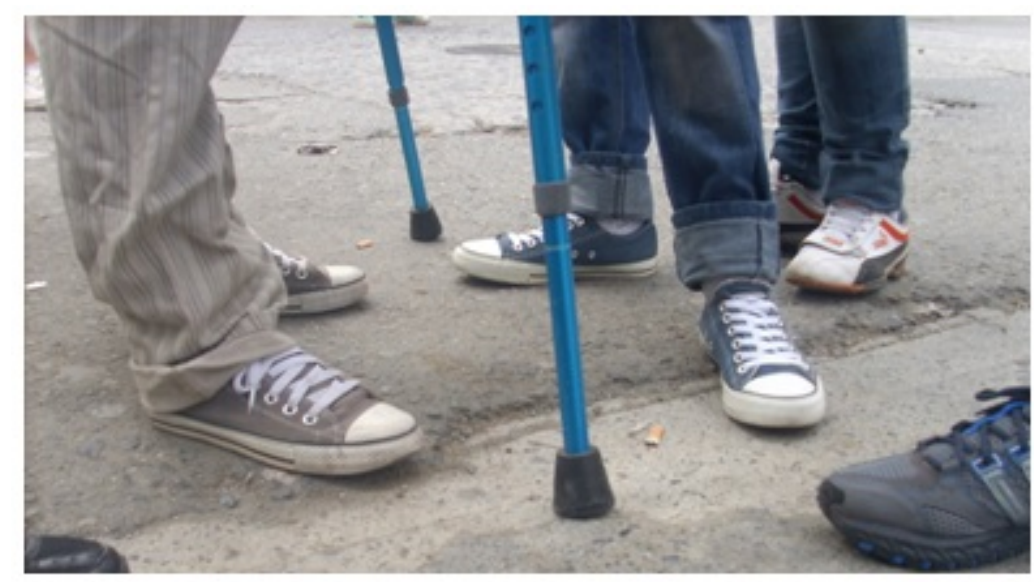

Fotografía 18. Victorino, Parque San José. Año: 2011. Archivo: FOCUS.

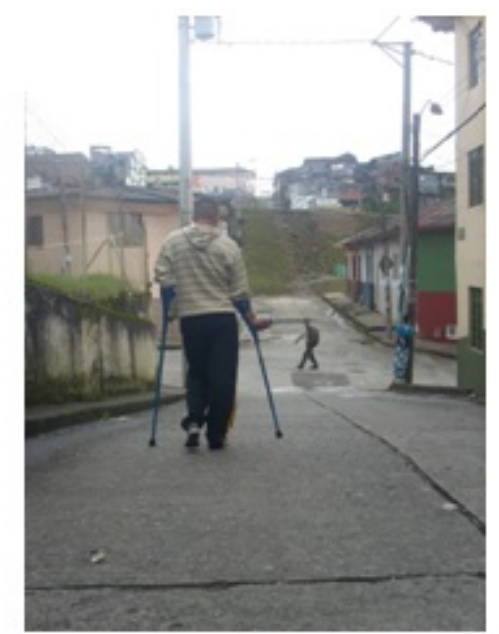

Fotografía 19. Victorino en el barrio La Pelusa, calle 30 con carrera 15. Año: 2011 Archivo: FOCUS.

Este par de soportes metálicos han cobrado un valor significativo no solo para Victorino sino también para la gente que se relaciona con él, representando tanto el esfuerzo físico como la energía mental por sobreponerse a las múltiples adversidades que traen consigo los inconvenientes sociales, económicos, culturales y psicológicos de la delincuencia, la pobreza y el abuso de las drogas, que no solo oscilan entre la discapacidad física y/o mental, sino también entre los escenarios carcelarios y funerarios que tanta representatividad tienen en estos contextos hostiles de manifestación múltiple de violencia y abusos. En este 
ámbito nos importa concentrar al espectador en aspectos de Victorino que sobrepasen por su condición actual de movilidad limitada, y lo lleven a comprender las vicisitudes de la usanza y la interacción que este actor social vive con estos soportes metálicos dentro de los espacios públicos y privados de la Comuna San José, un paisaje que continuamente se está transformando por factores macro y micro, de los cuales él hace parte indefectiblemente, al participar activamente de la comunidad y asumir un papel de liderazgo e intervención social dentro de ella.

Uno de los ejemplos más recientes de estas transformaciones, son los cambios sufridos por la familia de Victorino al tener que abandonar a comienzos de este año (2013) la vivienda que por más de cuatro años habían habitado pagando mensualmente un arriendo para vivir colectivamente allí, compartiendo el espacio familiar de manera altruista y paralela, en el cual se fueron distribuyendo los hogares de algunos de sus hermanos y hermanas en compañía de sus parejas y sus primogénitos, conformando una familia numerosa en la que su madre sigue siendo una cabeza visible en la organización y el liderazgo de las ocho personas y los tres hogares que la conforman.

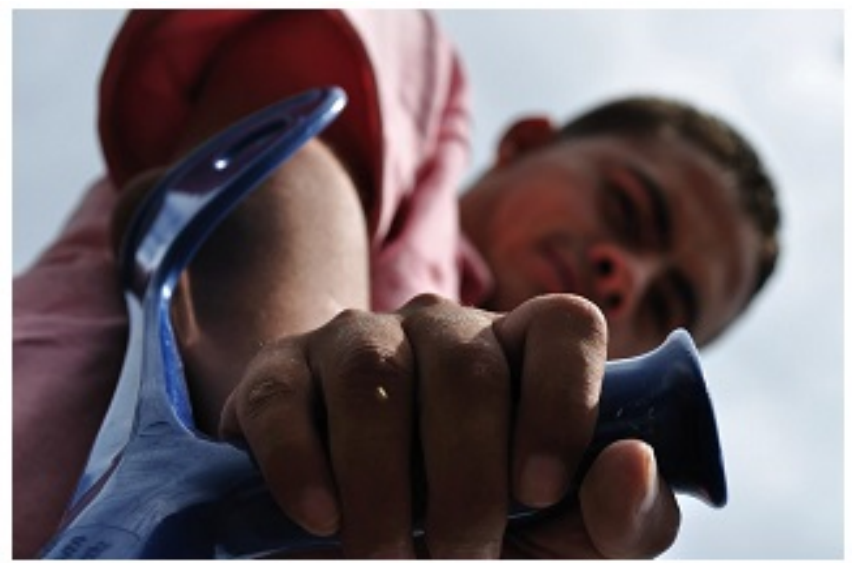

Fotografia 20. Victorino. Año: 2010. Archivo: FOCUS.

Doña Teresa, la madre de Victorino, ha sido una de las personas que emocional y corporalmente ha sufrido con más rigor la incertidumbre de no poseer una vivienda propia dentro de la Comuna San José. Con esto se ha venido reconociendo que los más afectados con el proyecto de ordenamiento territorial en este sector de Manizales, son los hogares sin un techo propio, aquellos que histórica y territorialmente han gozado de la vida comunal y la ubicación estratégica en el Centro de la ciudad, pagando una remesa mensual, generalmente por el alquiler de una unidad habitacional integral. En la Comuna es usual encontrar viviendas gigantes que albergan distintas familias y hogares de manera paralela, en la que los propietarios no son residentes del sector pero están a cargo de la prestación del servicio de renta y el cobro de la misma.

Cuando llegó la notificación del desalojo por parte del propietario de la vivienda, en el mes de noviembre de 2012, según el mandato de la empresa de renovación urbana, doña Teresa pensó en la necesidad de mantenerse con su familia en las inmediaciones de la Comuna San José, ya que no quería ver afectada su relación familiar con el Centro de la ciudad, pues allí se desenvuelven por ejemplo, sus relaciones comerciales 
de carácter informal, sin pagar ningún medio de transporte, como ocurre también con algunos de sus hijos y nietos que se desplazan hasta allí a realizar sus labores cotidianas de estudio o trabajo. Uno de esos casos paradigmáticos, es el de su hijo Víctor (Victorino), quien no solo ha creado un vínculo importante con el Centro de la ciudad, sino que también sostiene relaciones de gran valor comunitario y social con distintos vecinos de la Comuna San José, especialmente con jóvenes y personas adultas de los distintos barrios de la Comuna.

Doña Teresa, sin embargo, a principios de 2013 se ve obligada a mudarse de la Comuna ante la inminencia de la demolición de la vivienda que compartía cómodamente con su unidad familiar, teniendo que reconfigurar sus dinámicas cotidianas inicialmente en un barrio fuera de la Comuna, el cual conserva una cercanía importante con el Centro de Manizales y sus activos sociales, pero infortunadamente no permite un desenvolvimiento pleno de las relaciones sociales que previamente había elaborado en San José. Esto es especialmente cierto para Victorino, quien depende en gran medida de ese entramado cultural que ha ayudado a tejer en la praxis cotidiana de su Comuna, especialmente a partir de los actos cotidianos, solidarios y educativos, que desde hace más de dos años viene desarrollando de manera mancomunada con diferentes entidades tanto gubernamentales, como no gubernamentales, incluyendo agencias de la Iglesia Católica. Su praxis se ha realizado recientemente con la Pastoral Social, Fesco y el Centro de Escucha. También otras organizaciones, incluyendo la naciente Fundación de Lucha contra la Pobreza, y los muy importantes apoyos al accionar del Colectivo Antonio García y FOCUS.

La necesidad de volver a la Comuna se plasmó de nuevo en la mudanza rápida al interior de la misma, esta vez a un barrio más próximo del Parque San José, a una vivienda que habitacional y espacialmente está mejor equipada para las condiciones familiares, económicas, sociales y territoriales de la familia de Victorino y en contravía de las proyecciones institucionales que esperan que todos los habitantes sean desplazados de un lugar que de un modo $u$ otro han apropiado.

\section{EPÍLOGO}

Victorino como referencia de nuestra construcción de discurso ha propiciado medir la fuerza de la etnografía audiovisual, como forma crítica de narrar la realidad, no como instrumental para acercar los objetos de la investigación a los académicos. Las imágenes condensadas en los álbumes familiares, así como aquellas que aparecen en las grabaciones de audio o las que impiden conciliar el sueño cuando llegan como imágenes, voces, olores; incluso las percibidas a través de los cuadros y gráficas elaboradas con el uso de formas de software (SPSS, Atlas-Ti, entre otras), han permitido enriquecer nuestra vida personal y profesional. Aspiramos correlativamente a que la autoconciencia de individuos, familias y comunidades también les hayan enriquecido. Sin duda la autorrepresentación ha aportado en el desarrollo de las gentes de la Comuna. Esperamos que la lógica de la razón y de lo razonable, auspiciadas por investigaciones como las aquí entregadas como producto, impacten las conciencias de quienes deben asumir las responsabilidades por definir el futuro de 28.500 almas. 
La condición actual de la gente en la Comuna San José aunque pareciera ser inédita por las singularidades de la construcción del territorio, las condiciones de la pobreza y la pobreza extrema, la convivencia cotidiana con el microtráfico de sustancias psicoactivas y la construcción de redes sociales muy fuertes propias de comunidades humanas urbanas barriales, reproduce en las montañas de una ciudad intermedia como Manizales el trasfondo político y cultural, que permite que una política pública como el Macroproyecto de Renovación Urbana, antidemocrática por excelencia, destruya la historia de una Comuna completa, redefiniendo a la fuerza la vida cotidiana de hombres, mujeres, niños, niñas y jóvenes. En pocas palabras, las políticas públicas sin público, sin ciudadanos, solo pueden arraigar en una nación y una ciudad donde la democracia es solo un término manoseado, reducido a la huera palabrería mediática, con la participación ciudadana rebajada a socialización con entretenimiento y refrigerio incluidos.

La democracia como espectáculo es síntesis de una sociedad que pretendiendo ser moderna, enajena la libertad y los derechos en la toma de decisiones en quienes se arrogan su representación, ya espiritual en la moral que orienta la vida cotidiana individual y familiar, ya política en la definición de la vida social. La renuncia a los derechos constitucionales y legales de la participación democrática convierte a los formalmente denominados ciudadanos en clientes. Renuncia que corresponde a la sujeción de las conciencias ciudadanas por las formas del poder político, administrador en realidad de puestos públicos, contratos, becas, mercados y una cantidad enorme de prebendas que atan la simple subsistencia de los pobres a los lazos de políticos, organizaciones caritativas y usureros de todo tipo. Sociedad que pretende ser moderna, pero que solo sigue reproduciendo las relaciones hacendatarias de tiempos inmemoriales que ataban al peón y a su familia a los intereses de los poderosos.

El desplazamiento forzado, el desarraigo del mundo construido como vecindario urbano, como barriada popular, destruye sus referencias humanas, individuales, familiares y comunitarias, le recluye en $45,15 \mathrm{~m}^{2}$, rompiendo las redes sociales construidas paso a paso, en la existencia cotidiana. Se rompe el hábitat, el nicho construido que solo se valora cuando se pierde o se está a punto de morir, literal o metafóricamente. Como cuando un ser querido muere, humano, animal o planta y se siente el vacío dejado. No es un simple juego como el ajedrez, que se pierde una partida y se puede iniciar de nuevo. No es un juego virtual, de roles, tampoco. No es un juego, es la vida que ha sido desgarrada, que ha sido destrozada y que de pronto encuentra nuevas reglas, no concertadas, no consensuadas, solo impuestas por el poder. Se trata de los impactos psicosociales producidos por la demolición del entorno construido colectivamente. Impactos psicosociales no estudiados, no contemplados (con seriedad, se entiende) y por ello desconocidos, es decir, ignorados y soslayados.

¿Cómo suturar las heridas producidas en los habitantes de la Comuna, si son heridas emocionales que calan profundamente en el alma humana? No es posible alejarse del vecindario disfrutado y sufrido, de los amigos, de la familia, de la vivienda (de la casa en realidad, o del hogar) sin sentir nada. Se trata de vecindarios compartidos por 20, 30, 50 o más años. Tal vez se trata de una casa de lote humilde, pero es la que otorga la seguridad y la tranquilidad, junto con la lumbre que se encuentra al volver cada noche después de trabajar o estudiar. ¿Cómo se realiza el duelo por la vida perdida? Esto es lo que hace la vida humana, como ciudadana, como 
ciudadano, no la formalidad de la ciudadanía reducida a la existencia jurídica. La ciudadanía es mucho más que ello, lo sabemos todos, pero si se requiere que una autoridad filosófica lo reafirme, podemos traer en nuestra ayuda a Victoria Camps y otros intelectuales (Democracia sin ciudadanos), en lo que refiere a las formas reducidas de vivir la democracia en estos tiempos, en la delegación de la libertad y los derechos y la ausencia de formación cívica que no puede ser otra que "la transmisión de los mínimos éticos requeridos para convivir en democracia". (Camps et al., 2010, p.14).

Al lado de la libertad y la igualdad apareció históricamente la fraternidad, como pilar en la construcción de la democracia liberal. ¿Qué ha pasado con la fraternidad, con la necesidad de preocuparse y ocuparse con los asuntos de los otros? Se ha perdido en alguna parte en los más de dos siglos de su promulgación desde los tiempos de la Revolución Francesa. Se le ha dado hoy el nombre de solidaridad, sin diferenciarse de la caridad propia de tiempos de la vida estamental. Aparece como moda, devaluada en la grandilocuente responsabilidad social de las empresas. El Artículo 25 de la Declaración Universal de los Derechos Humanos dice textualmente: "Toda persona tiene derecho a un nivel de vida adecuado que le asegure, así como a su familia, la salud y el bienestar, y en especial la alimentación, el vestido, la vivienda, la asistencia médica y los servicios sociales necesarios", pero para que ese logro sea real se requiere lo que reza el Artículo 28 de la misma Declaración: "Toda persona tiene derecho a que se establezca un orden social e internacional en el que los derechos y las libertades proclamados en esta Declaración se hagan plenamente efectivos". Estos derechos proclamados en 1948 solo pueden hacerse reales con un ordenamiento democrático, pero también con una formación moral (la moral no es un asunto meramente de beatas y almas caritativas) que fuerce la conciencia de cada ciudadano para hacer respetar esos derechos. Solo así se puede tener una masa crítica de ciudadanos manizaleños que deje de mirar desdeñosamente a los habitantes de comunas pobres como un problema, como un riesgo, como asunto probablemente judicial y se atreva a mirarse en ellos como sus próximos, sus conciudadanos, sus otros que en últimas viven lo mismo que los más acomodados, solo que lo viven distinto. Es un deber ciudadano, asumir que los problemas de la Comuna San José son asuntos que le competen a toda la ciudad.

Ahora bien, más allá de la denuncia, asumida como crítica de la realidad social desde la etnografía visual o audiovisual, que sugiere de todos modos un nuevo horizonte por construir con las comunidades humanas organizadas afectadas por los procesos de renovación urbana, se asume la responsabilidad de seguir construyendo-reconstruyendo la memoria colectiva, que no es otra cosa que aportar en la configuración de la ciudadanía, la cual hasta ahora solo ha sido un propósito a alcanzar o a lo sumo una ilusión del ejercicio de los deberes y los derechos, reducidos al derecho al sufragio en los rituales políticos periódicamente planificados.

Victorino como referencia, Victorino como síntesis de la vida de los jóvenes en la Comuna, Victorino como posibilidad de emancipación de la vida de las comunidades pobres de la sospecha de distintas formas de criminalidad y de degradación vía consumo de sustancias psicoactivas. Victorino como imagen de la probabilidad real de la recuperación individual y comunitaria de la autonomía ciudadana vía formación académica acompañada del trabajo con los otros, con los próximos, en la dedicación a los jóvenes y los niños, en diálogo con los saberes de los investigadores sociales 
(antropólogos y sociólogos, entre otros), presenta elementos de lineamientos de política que puedan ser contemplados en la reformulación del Macroproyecto.

Por lo supracitado, Victorino es mucho más que Víctor Caicedo, es apostar a encontrar la fuerza en sí mismo, en cada individuo, en cada hogar, en cada calle y en cada barrio. Continuar cultivando los atributos barriales de la solidaridad, la cooperación, la confianza entre iguales, la recursividad, la iniciativa y las habilidades comunicacionales que forjan en cada esquina, en cada cuadra, en cada manzana, en cada canaleta, en cada barrio, territorios de encuentro, de memoria y cultura. En suma, seguir construyendo desde lo individual y lo colectivo, desde lo público y lo privado, la riqueza inmersa de lo popular, reivindicando prácticas sociales, económicas y políticas ancestrales, que anidan en cada conciencia, en los álbumes familiares, en las imágenes de los muros y en los recuerdos que afloran en cada historia oral, en cada fiesta y en cada momento de celebración ya secular, ya religioso.

\section{REFERENCIAS}

- Belting, H. (2002). Antropología de la imagen. Buenos Aires: Katz Editores.

- Bourdieu, P. (1965). Un arte medio. Ensayo sobre los usos sociales de la fotografía. Barcelona: Gustavo Gili.

- Camps, V. et al. (2010). Democracia sin ciudadanos. Madrid: Editorial Trotta.

- Cantor, F. et al. (2010). El carácter social de la Comuna San José de Renovación Urbana. Manizales: Universidad de Caldas. Sin Publicar.

- García, C. (2006). Una lectura antropológica de la fotografía familiar. Jornadas Imagen, cultura y tecnología (pp. 153-166). Getafe: ICTMU.

- García, O. y Arias, O. (2007). La tienda tradicional en la mente del consumidor manizaleño. Manizales: Universidad de Manizales.

- Harvey, D. (2008). El derecho a la ciudad. New Left Review, 53.

- Horkheimer, M. y Adorno, T. (2001). Dialéctica de la llustración. Madrid: Editorial Trotta.

- Marx, K. (1982). Manuscritos económicos y filosóficos de 1844. Marx Escritos de Juventud. México, D.F.: Fondo de Cultura Económica.

- Naciones Unidas. (1948). Declaración Universal de los Derechos Humanos. Asamblea General de las Naciones Unidas, París.

- Naranjo, J. (2006). Fotografía, antropología y colonialismo. México. Editorial Gustavo Gill.

- Pike, Kenneth. (1991). La relación del lenguaje con el mundo. Lima: ILV.

- Poole, D. (2000). Visión, raza y modernidad: una introducción al mundo Andino de la imágenes. Lima: Casa de Estudios del Socialismo.

- Ricoeur, P. (2008). La memoria, la historia, el olvido. Buenos Aires: Fondo de Cultura Económica.

- Robledo, J. (1996). La Ciudad en la Colonización Antioqueña: Manizales. Bogotá, D.C.: Editorial Universidad Nacional. 
- Sontag, S. (1981). Sobre la fotografía. Barcelona: Edhasa.

- Zapata, D. (2012). La nación en cuadro. Trabajo de Grado en Sociología (laureado). Manizales: Universidad de Caldas.

1. Sociólogo, docente e investigador de la Universidad de Caldas. E-mail fernando.cantor@ucaldas.edu.co

2. Antropólogo. Máster en Antropología Visual y Documental Etnográfico. Docente e investigador de la Universidad de Caldas. E-mail miguel.rivera@ucaldas.edu.co

3. Antropólogo. Docente e investigador de la Universidad de Caldas. E-mail julian.ramirez@ucaldas.edu.co

4. Desde el Colectivo de Investigación sobre la Realidad Social Antonio García y Laboratorio de Análisis y Producción Audiovisual desde las Ciencias Sociales -FOCUS-, hemos llamado la atención a través de al menos tres investigaciones realizadas. Del mismo modo el Comité de Voceros de la Comuna San José, como organización cívica de los vecinos; la Corporación para el Desarrollo de Caldas, entre otras, así como sectores políticos y de otras orillas de la academia, han contribuido a llamar la atención sobre los efectos negativos del Macroproyecto en las comunidades humanas.

5. Juan Manuel Llano, alcalde de Manizales 2007-2011, en su intervención ante la Comisión Quinta del Senado de la República al defender el Macroproyecto de Renovación Urbana de la Comuna San José, subrayó la pertinencia del Macroproyecto por impactar unas ratoneras en donde la gente vive peor que los perros de la gente pudiente.

6. David Harvey en su ensayo "La lucha por la ciudad", plantea básicamente dos formas a través de las cuales se acumula capital en este tiempo de globalización: la guerra y los megaproyectos urbanísticos. Estos últimos se realizan sobre la base de la desposesión de los propietarios, lo cual implica el desplazamiento forzado legal de ingentes cantidades de comunidades urbanas.

\section{Para un ejemplo, ver: http://www.museodelosdesplazados.com}

8. Decimos desplazamiento forzado porque como concepto expresa de mejor manera el proceso vivido en la Comuna San José, que el eufemismo suavizante empleado por colegas académicos y técnicos del desplazamiento: reubicación o reasentamiento involuntario inducido por procesos urbanos. Es similar al desplazamiento forzado de cinco millones de colombianos, calificados por el asesor del presidente Álvaro Uribe Vélez, José Obdulio Gaviria, no como desplazados sino como migrantes, tratando de limpiar todo el trasfondo político y militar que ha supuesto la agresión sobre los territorios campesinos e indígenas, de una política oficial, que va de la mano de la acumulación de capital vía desposesión.

9. En el foro realizado el 3 de abril de 2013 sobre el Macroproyecto, las entidades de Estado señaladas, así como sectores académicos, coincidieron en que dos de los principales problemas del mismo están en la 
falta de participación ciudadana y la ausencia de planeación en todas sus líneas.

10. "El Megaproyecto de Renovación Urbana en la Comuna San José: una mirada crítica e interdisciplinaria desde las ciencias de lo social", es una investigación financiada por las Vicerrectorías de Investigaciones y Postgrados y de Proyección Universitaria de la Universidad de Caldas. Solo queda por realizar la entrega formal en septiembre de 2013.

11. Particular importancia cobra el hecho de que el $46 \%$ de las jefaturas de hogar son femeninas.

12. El salario mínimo mensual se sitúa actualmente en $\$ 589.000$ (U\$312,40). Para mayor claridad en los lectores fuera del escenario colombiano, precisamos las cifras en dólares del siguiente modo: los $\$ 180.000$ (U\$95,39); $\$ 140.000$ (U\$74,19) y los $\$ 320.000$ (U\$169,58), se elaboran sobre la base del precio del dólar al cerrar el mercado el 26 de julio: mil ochocientos ochenta y siete pesos por un dólar (\$1.887 por U\$1).

13. Las viviendas en la Comuna San José siguiendo la tradición de los colonizadores, están construidas con bahareque, esterilla y guadua, materiales fungibles pero que les han dado y siguen otorgando la posibilidad de construir con materiales de la región, baratos y manejables. Sobre el particular, son de importancia capital las investigaciones realizadas por el crítico del Macroproyecto el arquitecto y Senador de la República, Jorge Enrique Robledo. (1996).

14. Para indagar sobre la vida y obra de Jorge Preloran se sugiere visitar el link: http://www.taringa.net/posts/tv-peliculas-series/5676468/PreloranDocumentales.html

15. La primera parte de este seguimiento se puede ver en el documental "Viviendo la Comuna" del colectivo FOCUS en asocio con el Colectivo Antonio García. Disponible en: vimeo.com/14247092

Para citar este artículo: Cantor, F., Rivera, M. A. \& Ramírez, J. A. (2013). La comuna San José en la mira: transformaciones urbanas y redes sociales vistas a través de la fotografía. Revista Luna Azul, 37, 162-195. Recuperado de http://lunazul.ucaldas.edu.co/index.php?option=content\&task=view\&id=851 